NBER WORKING PAPER SERIES

\title{
DUMPING AND ANTIDUMPING DUTIES
}

Bruce A. Blonigen

Thomas J. Prusa

Working Paper 21573

http://www.nber.org/papers/w21573

\author{
NATIONAL BUREAU OF ECONOMIC RESEARCH \\ 1050 Massachusetts Avenue \\ Cambridge, MA 02138 \\ September 2015
}

We would like to thank Meredith Crowley, Pinelopi Goldberg, Doug Irwin, Ohyun Kwon, Jee-Hyeong Park, Nina Pavcnik, and Hylke Vandenbussche for their comments and suggestions. We are especially indebted to Chad Bown for his insights and very detailed comments on a preliminary draft. Any omissions and mistakes are ours. The views expressed herein are those of the authors and do not necessarily reflect the views of the National Bureau of Economic Research.

NBER working papers are circulated for discussion and comment purposes. They have not been peerreviewed or been subject to the review by the NBER Board of Directors that accompanies official NBER publications.

(C) 2015 by Bruce A. Blonigen and Thomas J. Prusa. All rights reserved. Short sections of text, not to exceed two paragraphs, may be quoted without explicit permission provided that full credit, including (C) notice, is given to the source. 
Dumping and Antidumping Duties

Bruce A. Blonigen and Thomas J. Prusa

NBER Working Paper No. 21573

September 2015

JEL No. F13

\begin{abstract}
$\underline{\text { ABSTRACT }}$
The majority of the world's countries have antidumping (AD) statutes in place, hundreds of AD actions occur annually across these countries, and AD criteria and procedures have been codified in the General Agreement on Tariffs and Trade and its successor, the World Trade Organization. AD's unique characteristics along with its high incidence of use make it a particularly apt policy for studying numerous trade theories and political economy models. We review the economics literature on dumping and antidumping activity, with particular emphasis on the evolution of the literature and the most recent contributions. We also point the reader to resources and rich data available to study $\mathrm{AD}$, as well as our thoughts (in a concluding section) on where scholars should next focus their attention in this literature.
\end{abstract}

Bruce A. Blonigen

Department of Economics

1285 University of Oregon

Eugene, OR 97403-1285

and NBER

bruceb@uoregon.edu

Thomas J. Prusa

Department of Economics

New Jersey Hall

Rutgers University

New Brunswick, NJ 08901-1248

and NBER

prusa@econ.rutgers.edu 


\section{Introduction}

Loosely speaking, the term "dumping" denotes a situation when a firm charges a lower price in a foreign market than it charges for the same good in its domestic market or when it exports the good at a price below costs. This may significantly impact other firms in the destination market, putting downward pressure on prices and profits for suppliers in the market. In the early $20^{\text {th }}$ century, a few developed countries, beginning with Canada in 1904, enacted antidumping (AD) laws to remedy situations where foreign firms dumped products into their domestic markets due to worries about its effect on domestic firms. ${ }^{1}$

Today, the majority of the world's countries have antidumping statutes in place, hundreds of $\mathrm{AD}$ actions occur annually across these countries, and $\mathrm{AD}$ criteria and procedures have been codified in the General Agreement on Tariffs and Trade (GATT) and its successor, the World Trade Organization (WTO). Unlike many other forms of trade protection, AD actions are legal in the WTO and exempt from the nondiscrimination clause, as they remedy what are deemed to be unfair trade practices.

In this chapter we review the economic literature that has developed on $\mathrm{AD}$ activity, with particular emphasis on the past decade of research in this area. There are a number of reasons why we think the study of AD activity is interesting from an economic and policy standpoint, and has therefore led to a substantial and growing body of literature that merits its own chapter in this Handbook.

\footnotetext{
${ }^{1}$ New Zealand (1905), Australia (1906), South Africa (1914) and the United States (1916) followed suit after Canada with similar antidumping laws.
} 
From a theoretical point of view, AD laws and activity are interesting for a number of reasons. First, it is a codified exception in the rules of the WTO that otherwise work toward freer trade amongst WTO members and this leads to a number of interesting questions. In what sense do $\mathrm{AD}$ laws serve the larger goals of the WTO? AD laws may be an important release valve or insurance policy that allows countries to achieve greater multilateral gains on other fronts. On the other hand, WTO members may be substituting one form of trade protection for others and attenuating free-trade gains.

Second, how consistent are AD laws with general WTO principles and framework, particularly since AD laws were developed well before the GATT and WTO came into existence? For example, AD actions can be (and almost always are) discriminatory across WTO members and do not have allowances for reciprocity or (limited) retaliation. Are the many AD-related disputes at the WTO an indication of these inconsistencies or due to other factors?

Third, political economy implications of $\mathrm{AD}$ actions are also fascinating. $\mathrm{AD}$ actions are quite different from many other forms of trade protection in that they are administered by government agencies and typically do not require executive or legislative action. Does this make AD protection more or less prone to political pressure? Also, AD actions typically begin with a petition by an interested domestic party (i.e., competing domestic producers) and provide little to no voice for consumers who will be affected. These characteristics generate a unique political economy setting to study. Finally, the relative ease of initiating AD actions also 
makes $\mathrm{AD}$ subject to possible strategic manipulation by firms who compete against each other in the market place.

Fourth, many of the details of implementing AD laws have evolved over time. In addition, implementation varies across products and countries, which can lead to a wide range of possible outcomes depending on the particular implementation. An obvious and well-researched example is the impact of how agencies define and measure "dumping" and "injury to the domestic industry", the two key implementation criteria. A firm pricing identically in two exports markets may be deemed to be dumping by one country, but be found not to have dumped by the second country. Also, AD measures are subject to frequent and systematic review to determine if their application is still merited. How agencies implement these reviews and the strategic responses of firms can lead to a wide variety of outcomes.

From an empirical perspective, $\mathrm{AD}$ actions have a number of features that generate clear testable predictions. To begin with, its heavy use makes AD a natural policy to study. AD remains the predominant contingent trade policy instrument for most WTO members. Prusa (2005) reports that there are more antidumping actions than all other contingent protection measures combined. Bown (2010, 2011) shows that antidumping protection accounts for the vast majority of all the trade subject to any temporary trade barrier. In terms of trade policy, AD is where the action is.

Moreover, $\mathrm{AD}$ investigations involve a relatively short administrative process. As a result $\mathrm{AD}$ measures occur frequently and can respond fairly quickly to changing economic circumstances. For the past several decades these administrative 
decisions have been fairly well documented by government agencies. In recent years AD activity across all users has been regularly updated by the World Bank (Bown, 2014a). As a result, AD activity generates substantial "data points" that are about the closest one can get to real-time data on trade protection actions.

The implication of the intensity of $\mathrm{AD}$ activity is two-fold. First, because $\mathrm{AD}$ actions are typically targeted to very specific import sources and products researchers have been able to precisely examine the effects of these trade policies on the targeted sectors. Combining information on AD actions with other detailed data related to those sectors has resulted in important tests of trade effects on micro-level activity (e.g., plant, households, etc.). Second, the aggregate and cumulative effects on the economy from the many disparate targeted actions can be measured. Gallaway, Blonigen, and Flynn (1999) and Messerlin (2001) offer evidence that the welfare costs associated with AD protection are among the largest of all commercial trade policies.

In summary, $\mathrm{AD}$ laws and resulting protection are unusual in many ways, while clearly intertwined with other trade policies and cross-country efforts to lower trade barriers. The variation in the country-specific implementation of $\mathrm{AD}$ rules leads to a variety of interesting research pursuits that span not only the trade policy literature, but also the applied game theory, industrial organization, and political economy literatures. The frequent and well-documented activity provides empirical researchers with rich data to explore hypotheses.

In the rest of this chapter, we first set the stage by providing a quick overview of the history and basics of AD laws, followed by what we think are salient 
features about AD activity across time, products and countries in the world economy. We then review the fundamental economic issues surrounding AD laws and activity that researchers have examined and addressed in what we consider the traditional and well-established literature on AD that date backs many decades. In section $\mathrm{V}$, we turn to the more recent work on $\mathrm{AD}$ that has occurred in the past decade or so.. ${ }^{2}$ We conclude with a section outlining where we see the literature headed in the coming years.

\section{A Brief Primer on the History of AD Laws and Basics on Implementation}

\section{A. History of AD laws}

The origins of antidumping laws date back to 1904 when Canada was the first country to adopt laws that allowed for special duties on "under-valued goods", where the duty would be calculated as the difference between the price in Canada and the price at which goods were sold in the exporter's own market. The impetus was competitive pressures on the Canadian steel industry from cheap imported U.S. steel, while similar pressures in the agriculture machinery industry from the U.S.firm International Harvester led Australia (1906) to quickly follow with a similar law. (Ciuriak, 2005)

The broader context to the origination of these laws was the public response

\footnotetext{
${ }^{2}$ For us, this roughly corresponds to the period of time since we last wrote a review of the AD literature (Blonigen and Prusa, 2003). An alternative perspective on the literature can be found in Nelson (2006). WTO (2009) offers a broad discussion of the contingent protection literature, including antidumping.
} 
to the large monopolies and cartels that had arisen in the late $19^{\text {th }}$ and early $20^{\text {th }}$ centuries in a number of Western developed countries, particularly in the U.S. Beginning with the Sherman Antitrust Act of 1890 and followed by other refinements, including the Clayton Act of 1914 and the Robinson-Patman Act of 1936, the U.S. made illegal many business practices that harmed or limited market competition. One of the business practices made illegal with the Clayton Act of 1914 and the Robinson-Patman Act of 1936 was price discrimination that is predatory in its intent; i.e., pricing low with the intent of driving competitors out of the marketplace. The first antidumping legislation in the U.S., the Anti-dumping Act of 1916 largely applied this principle to imports, making it illegal to sell imports at low prices "with the intent of destroying or injuring an industry in the United States, or of preventing the establishment of an industry in the United States."3

Showing (predatory) intent on the part of a firm to injure competitors is legally difficult and a U.S. Tariff Commission report in 1919 concluded that the 1916 law did not cover a broad enough range of dumping activities that could be harmful to U.S. producers, whether there was predatory intent or not. (Mastel, 1998, p. 19) As a result, the U.S. enacted the Anti-dumping Act of 1921, which provides a considerably different standard. ${ }^{4}$ As Irwin (2005) discusses, the change is from a (1916) law that is a criminal statute with criminal punishments for predatory pricing practices to an administered import policy that levies duties on a foreign firm for simply charging lower prices in the U.S. than the firm's own home market.

\footnotetext{
${ }^{3}$ Quoted in Irwin (2005), p. 652.

${ }^{4}$ Curiously, the 1916 Act was not repealed and it remained an option to remedy dumping. In 1998 the WTO Appellate Body ruled it violated WTO rules; in 2004 the U.S. finally repealed the 1916 Act.
} 
Barceló (1991) provides evidence that many U.S. legislators did not really understand this conceptual change at the time, though others feared that it would lead to an easier path to import protection. It is clear that this change made the U.S. law much more comparable to those passed in Canada and other countries adopting similar laws at the time.

In the decades that followed, special forms of protection like antidumping were rarely used as countries began to implement substantial increases in tariffs and quotas after the crash of 1929 and the onset of the Great Depression. But such special forms of protection were not forgotten in the initial negotiations and adoption of the GATT. Article VI of the original GATT in 1947 enshrines general language allowing signatories to employ antidumping and countervailing duty policies and closely follows the provisions of the 1921 U.S. Anti-dumping Act.

The early rounds of GATT were focused on reducing traditional forms of trade protection and did not make any substantive changes or additions to the $\mathrm{AD}$ provisions in Article VI. The Tokyo Round (1973-1979) included the first significant changes to GATT AD rules, broadening the rules for determining dumping to include "sales below costs" and clarifying what constitutes material injury (essentially codifying evolving EU and U.S. practices).

The Uruguay Round (1986-1994) made the most substantive changes to AD provisions in the GATT by rewriting Article VI from a set of general guiding principles to a very detailed description of how AD actions are to be implemented 
by WTO-member countries. ${ }^{5}$ While there were some refinements and new innovations to $\mathrm{AD}$ policies in this re-writing, the fundamental concepts of applying $\mathrm{AD}$ measures were unaltered and continued to be quite consistent with the existing national laws of the "traditional users" of AD laws (Australia, Canada, EU, and U.S.). ${ }^{6}$

We stress that since at least GATT 1947, the legal basis for imposing antidumping has had nothing to do with an economic understanding of dumping. For instance, economists often argue that dumping is only economically meaningful if imperfect competition exists, products are not homogeneous, and markets are segmented (e.g., limited price arbitrage). None of these economically meaningful concepts appear in the GATT (and later WTO) AD rules. The lack of economic principles makes AD very different from most other GATT provisions ${ }^{7}$ and is perhaps the greatest frustration of economists with respect to antidumping. Finger (1993) states "antidumping is just ordinary protection with a good public relations program."

\section{B. Implementation of $A D$ laws}

While countries can vary some in their implementation of AD laws, there is significant commonality, particularly due to the substantial codification of AD

\footnotetext{
${ }^{5}$ The changes to the rules were substantial enough to warrant moving the antidumping text to a new agreement, often called the Anti-Dumping Agreement. Article I of the Anti-Dumping Agreement refers back to Article VI of GATT.

${ }^{6}$ See Mastel (1998) for further details.

${ }^{7}$ Bagwell and Staiger (2016) review much of the literature providing economic explanations for many aspects of WTO rules.
} 
practices in Article VI of the GATT in the Uruguay Round. Acknowledging that there are differences across countries, in broad terms an $\mathrm{AD}$ investigation proceeds as follows. If a domestic industry believes that it is being injured by dumped imports, it files a petition with the relevant government agency(-ies). In nearly all cases domestic firms and/or labor unions submit the petition. Though more rare, government agencies charged with implementing $\mathrm{AD}$ laws are legally able to initiate investigations of their own volition.

With the petition filed the first step for the administrative agency(ies) is to determine whether the petition satisfies all requirements under the law to initiate an investigation. For example, is the petition is sufficiently supported by the industry, is the product precisely defined, is the basis for the alleged existence of dumping plausible, is the nature of the injury explained, etc.?

Once it is determined that a petition satisfies all requirements, the investigation proceeds on a statutorily defined timetable. For most countries the investigation lasts 12-15 months; the timeliness of the potential duty makes $\mathrm{AD}$ a very attractive policy for industries seeking import protection.

GATT/WTO rules specify two criteria must be met in order for an AD measure to be applied. The first is the presence of dumping defined as when the price of an imported good is below what is considered "fair" or "normal" value. The second criteria requires agencies to examine whether the dumping activity, if found, has materially injured the domestic industry or threatens to cause material injury. In some countries a single agency handles both the dumping margin calculation and 
injury determination, while in other countries the two determinations are handled by two different agencies.

\section{i) Dumping Margin Determination}

Dumping is defined as when the price of an imported good is below what is considered "fair" or "normal" value. Dating back to even the very first antidumping laws, the default measure of fair value is the price charged for the same good in the exporter's own market, after backing out transportation costs, border costs, exchange rate translations, etc., so that one is ultimately comparing the two prices for the product (the observed price in the import market and fair value) just as they leave the factory (i.e., ex factory prices).

In the mid-1970s an alternative method for determining dumping evolved, sales below costs. Under this method the investigating authority must determine if the exporter has sold a sufficient volume at prices below average total costs. To make this determination the authority will ask for detailed transaction price, cost, and other data from the exporters. Complying with these requests can be onerous for foreign firms. If below cost sales are found, the agency does not need to find any evidence of price discrimination. Rather, the dumping duty is designed to bring the export price above fully loaded costs plus a margin for overhead and profits. The fact that one of the most basic principles taught in any standard microeconomic class is that firms can find it optimal to sell below average total costs (but above average variable costs) is irrelevant for $\mathrm{AD}$ - such pricing is deemed unfair. Moreover, over the intervening decades the rules governing sales below cost have 
evolved and as a result the sales below costs method is now investigated in nearly every case. ${ }^{8}$

When the exporter's home market is deemed to be too small to be representative, investigating authorities can instead make its price comparison on the exporter's prices to third markets. This method effectively means AD duties are levied because the exporter charged a lower price in one destination market than in another.

Under all three methods if foreign firms do not cooperate with the investigating authorities' data requests, the authorities may use "facts available" to determine fair value and dumping margins, which can include information obtained from the domestic firms requesting the investigation. Not surprisingly, calculations based on facts available generally result in implausibly large dumping margins.

\section{ii) Injury Determination}

The second criteria requires agencies to examine whether the dumping activity, if found, has materially injured the domestic industry or threatens to cause material injury. This involves examining changes in market share and import penetration, as well as the indicators of the domestic industry's performance from output and employment to capital investment and firm bankruptcies. While there has been growing emphasis on establishing causality, not necessarily correlation, doing so is clearly difficult in most cases and current approaches do not satisfy economists' standards for identifying a causal effect.

\footnotetext{
${ }^{8}$ Clarida (1996) documents that approximately two-thirds of U.S. antidumping investigations involve the cost-based definition of dumping.
} 
Under the Uruguay Round rules, there must be a preliminary and final determination for both the dumping and injury tests. If both final determinations are affirmative, then antidumping measures can be imposed on imports of the product concerned. These measures usually take the form of an ad valorem duty, but could also be specific duties or price/quantity undertakings ${ }^{9}$, or a combination of all of the above. If duties are levied, they are paid by the importer not the exporter. In addition, most countries impose a preliminary dumping duty once an affirmative preliminary dumping determination has been made. These preliminary duties are held "on deposit" until the final determination and are reimbursed if the final determination is negative. Many countries calculate individual dumping margins for the foreign firms responsible for the largest share of the investigated product, with any remaining firms exporting the investigated product subject to an AD duty that is a (trade-weighted) average of the firm-specific dumping margins found by the antidumping authority.

While the WTO rules do provide broad guidance, countries (or, more specifically, the agencies tasked with the investigations) have broad latitude on how to interpret the rules. In a typical case there are literally hundreds of apparently small decisions that can significantly affect the final determination. This discretion is a key reason why we observe so many $\mathrm{AD}$ actions - a country can seemingly make duties as easy or as difficult as it wants. And, it also explains why we observe so many WTO disputes involve antidumping as agency discretion is often the basis for complaints.

\footnotetext{
${ }^{9}$ A price/quantity undertaking is an agreement by the exporter to raise its price to the market and/or lower its export volume to the market to a certain level.
} 
AD duties are meant to be in place only as long as injurious dumping continues. The Uruguay Round included a mandatory sunset review process. Under this provision, countries must review whether the duty is still needed a duty has been in place for five years (and every five years thereafter). Nevertheless, traditional users of $\mathrm{AD}$ laws have cases where $\mathrm{AD}$ duties have been in place for decades.

\section{Facts and figures on AD use}

As mentioned, data collection and documentation of $\mathrm{AD}$ activity is very good, particularly for the past couple decades. The WTO has tracked and documented AD activity by its member countries since its establishment in the mid-1990s. However, the information reported by the WTO is sparse and the WTO accounting is entirely dependent on timely and accurate member reporting. To make matters worse there is inconsistency in what countries report to the WTO.

Fortunately, the World Bank created and maintains a substantially more detailed database on AD activity by nearly all countries that at least occasionally use AD laws. This database is known as the Global Antidumping Database and is just one part of the World Bank's Temporary Trade Barriers Database, a project led by Chad Bown (Bown, 2014a). Much of the empirical work we discuss in section V uses case information contained in this database. The World Bank database is likely the first place a researcher should consult when beginning research on $\mathrm{AD}$, but it is not the only source of useful information on AD. In Table 1 we provide a list of some 
prominent online resources that we think provide excellent information on AD. We also note that the World Bank site contains additional links to individual country investigating authorities.

There are a number of important patterns in $\mathrm{AD}$ activity of which researchers studying dumping and antidumping should be cognizant. The first is the relatively recent proliferation of countries with $\mathrm{AD}$ laws. As seen in Figure 1, $\mathrm{AD}$ laws were in existence for just a handful of countries for the first fifty years after Canada first adopted an AD statute in 1904. There were then a couple large waves of adoptions since the middle of the $20^{\text {th }}$ century. The first saw about 30 countries add AD laws from 1950 through 1970, and the second was a more substantial wave of approximately another 80 countries from around 1990 to the early 2000s. The first wave was mainly developed European countries, many that would ultimately be part of the European Union, as well as some African and Caribbean countries. The second wave was mainly developing countries from all regions of the world, as well as former Soviet and Eastern Bloc countries. We note that the waves in AD law adoption occurred when there were substantial market integration events occurring in the world economy. The first wave occurred during, and in the wake of, a number of initial successful GATT rounds, as well as the beginning integration of developed Europe. The second wave was in the wake of substantial trade liberalizations in the developing world, the successful conclusion of the Uruguay Round, and the rising membership of countries to GATT/WTO.10

\footnotetext{
${ }^{10}$ In addition, members were not required to sign the GATT antidumping code through the Toyko Round. Because many GATT/WTO members, especially developing countries, did not sign the separate GATT AD code, they did not have an impetus to enact their own domestic AD legislation.
} 
A natural question is whether $\mathrm{AD}$ activity increased as the number of countries with AD laws increased. There are several ways to measure AD activity. The number of $\mathrm{AD}$ cases initiated and the number of applied AD measures (which could be duties or other outcomes like price undertakings) are probably the most commonly used, primarily because they are simple to calculate and require the least amount of information. In fact, until relatively recently they were the only metrics that could be calculated across a wide set of users. Remarkably, even these simple measures were difficult to compute in a comprehensive way until 1995 (postUruguay Round).

Figure 2 shows AD initiations and AD measures for WTO member countries from 1995 through 2013.11 Perhaps not surprisingly, AD measures and initiations are highly positively correlated at this aggregate level. From 1995 to 2002, one sees more than a doubling of AD initiations and measures, as one might expect with the concomitant spread of countries with new AD laws. However, since the early 2000s, AD initiations and measures have generally fallen back to 1995 levels. This decline in $\mathrm{AD}$ activity is a puzzle that the literature has not fully addressed and is a question which we will return to later.

Countries using AD laws are often separated into two groups - the traditional users (Australia, Canada, the European Union, and the United States) and the leading "new" users like Argentina, Brazil, China, India, and Turkey. Prusa (2001)

The Uruguay Round integrated the Antidumping Agreement into the single WTO undertaking. This resulted in many countries (finally) enacting an AD statute.

11 The WTO's "measures in effect" is a noisy metric of AD protection. Countries are supposed to report undertakings, but it is not clear they do so in a consistent fashion. Moreover, measures "in effect" captures neither the size of the AD duty, nor the breadth of coverage. 
reports that until the mid-1980s, the four traditional users accounted for more than 95\% of all AD actions. Prusa (2001) and Vandenbussche and Zanardi (2008) show that a number of "new" adopters of AD laws, particularly Argentina, Brazil, China, India, and Turkey, are largely responsible for the rising share of activity accounted for by new users. If one computes the share of $\mathrm{AD}$ activity due to new users one finds that at no time during the post-Uruguay Round period have the new users accounted for less than half of worldwide AD activity, and in most years they have accounted for more than $70 \%$ of the cases. Interestingly, most of the AD disputes initiated by new users have targeted imports supplied by other developing countries - South-South protectionism (Bown, 2013). The emergence of AD use by developing country users is arguably the most significant development in $\mathrm{AD}$ in the last two decades and remains a topic in need of additional study.

Bown (2011a, 2011b) has argued that the number of initiations and measures may not accurately portray the magnitude and effect of AD activity. AD measures can vary substantially from narrowly targeted actions to cases that impact a larger set of products; some cases involve just a single HS line while others involve dozens and dozens of tariff lines. Bown (2011a) offers two alternative metrics for evaluating $\mathrm{AD}$ coverage. One simple alternative is the fraction of a country's HS codes under AD order. Bown argues the HS count more accurately captures the scope of $\mathrm{AD}$ protection than a simple case count because coverage varies widely across cases. However, even the HS count metric will not properly capture the vast differences in trade value across cases. Bown's second (and in our view, preferred) metric is to trade-weight each HS line in each case. Under this latter metric, a case 
involving a single HS code which entails a large value of trade (e.g., U.S. imports of fresh salmon) would be appropriately measured as being "more important" than a case involving many HS codes with a modest amount of trade (e.g., U.S. imports of wire hangers). Like all value-based measures of protection, however, this second metric will be affected by the size of the duty. For instance, trade in a case with a $125 \%$ AD duty might fall to zero. A simple value based metric could lead one to infer no trade value is affected in that case, an obvious mismeasurement. To account for this issue Bown (2011a) offers a sensible approach to create a counterfactual measure of what the trade value in the affected HS lines would be "but for" the AD duty. His approach has been widely followed. ${ }^{12}$ We believe both of Bown's metrics have merit, especially his trade weighted measure, and academics are increasingly using his metrics to capture the extent of AD protection (e.g., Ludema and Mayda, 2011; Prusa, 2011; Vandenbussche and Viegelahn, 2011).

In Table $\mathbf{2}$ we report $\mathrm{AD}$ activity for each of the top $\mathrm{AD}$ users using the alternative metrics. The countries are sorted using the case count metric (column 2). The top ten countries using $\mathrm{AD}$ account for over $75 \%$ of all $\mathrm{AD}$ measures applied during this period, so there is substantial concentration in AD activity across countries. Besides the European Union and the United States, the top users of AD measures are the new users with India at the very top of the list with over $500 \mathrm{AD}$ measures from 1995 through 2013.

${ }^{12}$ All of the country specific analyses in Bown (2011b) use the HS line metrics of AD protection. 
Bown's HS metrics are reported in columns 3 and $4 .{ }^{13}$ There are a several comments worth making. First, all three metrics show (roughly) similar trends: countries with high case counts also tend to have larger HS coverage (correlation greater than 0.70). However, the relationship is noisy. For example, compare Brazil, China, and Turkey. All have a similar number of cases, but the Bown coverage ratios differ significantly. This suggests that Turkey's AD cases tend to include a large number of HS lines, but the value of imports covered in Turkey's cases is less than in China's cases. Second, all the measures show AD to be a very significant form of protection. Using the count metric, the largest users have 3-7\% of their tariff lines subject to AD scrutiny. Using the value metric the coverage tends to be a bit smaller, but still implies that almost $2 \%$ of EU imports, $4 \%$ of U.S. imports, and $6 \%$ of China imports are under $\mathrm{AD}$ orders. Given the size of the $\mathrm{AD}$ duties (discussed below), it is quite likely that $\mathrm{AD}$ is the largest trade protection policy used today for many developed economies. ${ }^{14}$

Table 2 also reports the countries that are most frequently targeted by AD measures. China has been the clear favorite target in recent decades concomitant with its rapid ascendancy into the global economy.15 Many other East and Southeast Asian countries are in the top ten and were primary targets of world AD measures

\footnotetext{
${ }^{13}$ We were unable to find the simple count metric for AD protection for all ten countries so we report the count metric for all TTB protection. This is a trivial distortion as virtually all TTB protection is due to AD protection (Bown, 2014a).

14 Gallaway, Blonigen, and Flynn (1999) estimates imply that AD was the second most costly barrier to trade behind the Multifibre Agreement through the early 1990s. Given that the Multifibre Agreement has been eliminated it is quite likely that $\mathrm{AD}$ is the trade policy that imposes largest welfare costs on using countries.

${ }^{15}$ Bown's HS metrics are not available by exporter so we only report case counts.
} 
before the rise of China. Interestingly, four of the top targets are also top users Brazil, China, India, and the United States.

Bilateral usage of AD is highlighted in Table 3. In this table we report bilateral $\mathrm{AD}$ use for each pair where the using country has applied 20 or more $\mathrm{AD}$ measures against a specific exporting country. For many of these pairs we also have the HS trade weighted metric of the import coverage. The extent that AD has focused on China is apparent. The six largest bilateral pairs all involve China as a target. The coverage is huge. For example according to Bown (2014a) over 23\% of China's exports to India, 9\% of China's exports to the U.S., 7\% of China's exports to the EU, and almost 19\% of China's exports to Brazil are under AD orders.

Interestingly, the highest bilateral coverage is not always associated with a large number of disputes. For instance, developing countries often export only a few HS codes. For these countries, a few AD actions can affect most of their exports. Table 4 reports the share of the target country's bilateral exports subject to contingent protection. We list all country pairs where the coverage exceeds $15 \%$. For some developing countries contingent protection affects the majority of their exports to the importing country.

One other important "fact" to note is that for both traditional and new users the average AD duty is considerably larger than the average applied MFN ad valorem tariff. This is one reason why $\mathrm{AD}$ is so attractive to protection-seeking industries there is a big bang for the buck! Data on AD margins are given in Table 5. As seen AD duties provide substantially higher protection than current average tariff levels. A couple of comments are warranted. First, some countries report AD duties for 
particular cases as specific duties or as a range (e.g., 20-50\%). Also, many countries often prefer to resolve AD disputes as undertakings. These agreements will generally not involve a duty, but rather be in the form of a price and/or quantity restriction. The equivalent ad valorem duties for all such outcomes are not included in the table. Second, the average AD duty is a very coarse indicator of the level of protection. Not only is there a range of duties in any given year (and often in any given case), but the duties can vary over time (Blonigen, 2006b). Thus, the average duties reported in Table 5 are at best a rough indicator of actual AD duties levied in any given year. Nevertheless, the summary statistics are compelling evidence that applied AD duties are often very large. And this raises the very real possibility that contingent protection, in general, and AD, specifically, can significantly "undo" hardwon tariff concessions.

A final set of patterns we highlight is the incidence of AD measures across types of products (Table 6). Activity is fairly concentrated in a few sectors, namely 1) Base metals and metal products, 2) Chemicals and allied products, and 3) Plastics and rubber products. These three account for over 60\% of AD measures from 1995 through 2013. And while they are large sectors, this share of AD activity is far larger than these sectors' share of world trade activity (either by value or weight). While one might expect that the traditional developed-country users would target very different products with their $\mathrm{AD}$ measures than the new developing-country users, this surprisingly is not true. Both new and traditional AD users apply many AD measures in these three types of products, though nearly half of AD measures by traditional users have been in the base metals category. This concentration of 
activity in certain products is another issue that has not been fully reconciled in the literature.

We stress that the industry counts reported in Table 6 are based on the simple case count metric. In a related chapter in this handbook, Bown and Crowley (2016) report cross-industry use by country using the HS line metric (discussed above). They report interesting differences across countries. For example, consider the textile industry. They find that about 70\% of Mexican textile HS lines are subject to trade protection. No other using country has more than $15 \%$ coverage in textiles, and most have less than 5\% coverage. Similar stark differences are found across a number of sectors. For instance, the U.S., EU, and India all have $15-20 \%$ of the HS lines in "steel and metal" under order. The other countries using AD have a tiny share of their "steel and metal" tariff lines under order. The patterns reported in Bown and Crowley (2016) suggest that the pattern of protection has much to do with the specifics of the AD-using countries' domestic industries, rather than systematic differences in "unfair" pricing by foreign suppliers.

\section{Key issues traditionally addressed in the economics and law literature}

The antidumping literature is fairly mature with significant contributions over the past three decades. This established literature has provided us important evidence on a number of key questions from when and why dumping occurs to its overall welfare effects. In this section, we provide an overview of this literature and its main conclusions, leaving much of the recent research contributions of the past ten years for the section $V$. 


\section{A. When and why does dumping occur?}

\section{i) Market structure explanations}

The original U.S. Antidumping Act of 1916 was concerned with penalizing foreign firms for predatory pricing practices against domestic firms, but this was soon replaced by a law allowing for remedies without the need to prove predatory intent. Nevertheless, in the public rhetoric surrounding dumping and justification for antidumping duties the predatory pricing story looms large. Hartigan (1994) provides a framework for thinking about the concern for predatory pricing. In his model there is a Bertrand duopoly and the domestic firm does not know whether the foreign firm's costs are low or high. If the foreign firm is a low cost producer, the domestic firm will be unable to compete successfully. By dumping, the foreign firm can, irrespective of its actual costs, act like a low cost competitor and induce exit by the domestic firm. Hartigan (1996) demonstrates that information issues in credit markets may also provide an opening for viable predatory pricing (dumping) by the foreign firm.

Despite its prominence in the public debate, evidence suggests that market conditions necessary for effective predation are rarely present in antidumping cases (Shin, 1998; Tharakan, 1999).16 Instead, modern laws and practical implementation of AD laws simply look for evidence of unfair pricing; i.e., a firm charging a lower price in their export market relative to either (i) the price in their own market or (ii) some constructed price based on its estimated costs.

\footnotetext{
16 Relatedly, the industrial organization literature is generally skeptical that predatory pricing is a common occurrence. See Kobayashi (2010) for a recent survey of the law and economics literature analyzing predatory pricing behavior.
} 
A seminal paper in the literature by Brander and Krugman (1983) provides a simple model of dumping based on price discrimination, often referred to as the reciprocal dumping model. To the extent that there is a canonical model of dumping in the literature, this is it. The setup has two Cournot firms, each located in separate countries such that it requires positive transportation costs for a firm to provide the good to the other country, but zero transportation costs to serve its own country. Both firms have identical production costs and both countries have identical demand conditions. Solving the model, both Cournot firms serve both markets in equilibrium provided that transportation costs are not too high. Given identical demand conditions, the equilibrium price in both markets is identical as well. For anyone familiar with Cournot models, this is not a surprising result. What is interesting is the observation that both firms are dumping into each other's country according to the basic definition of dumping. The price of the good before it is exported must be lower than the final price paid by the consumers in the export market by the amount of the transportation cost. Because there are no transportation costs for serving domestic consumers and the two markets have identical equilibrium prices, a firm is dumping when it fully absorbs the transportation cost needed to ship to the export market. While this model is quite simple, it is not difficult to see that dumping based on price discrimination is a phenomenon that can arise in many situations.

Brander and Krugman's (1983) analysis also points out that the welfare consequences of dumping in this context of price discrimination are ambiguous and perhaps even beneficial, which contrasts with typical welfare analysis of predatory 
pricing situations. Exporting involves incurring (wasteful) transportation costs, but the additional competition leads to lower prices in each market. Thus, the impact on net welfare depends on which of these two effects is larger. ${ }^{17}$

Another possible reason for dumping behavior that can stem from a benign motive on the part of the exporting firm is excess capacity. Staiger and Wolak (1992) provide a model where a foreign monopolist serves its own market and also exports to a competitive export market. The firm faces uncertain demand in its own market, where it can experience periods of both low and high demand and must make a sunk production capacity decision. It can be shown that there are conditions in which the foreign firm will pick a capacity whereby it will dump its excess capacity into the export market in low demand periods, but will alter its capacity choice to make dumping less likely when the export market has AD laws. This explanation for dumping and how $\mathrm{AD}$ laws help mitigate foreign firms from exporting poor demand conditions has been a primary argument for AD laws by some industry groups (e.g., see Howell, et al., 1988). Using U.S. steel import data Blonigen and Wilson (2010) find evidence for such excess-capacity dumping from certain import sources.

Ethier (1982) suggests an alternative mechanism by which firms rationally dump in certain periods due to conditions in their own home markets. If the foreign firm has restrictions on its ability to adjust its input costs, there will be an

${ }^{17}$ Anderson, Schmitt, and Thisse (1995) offer an interesting extension of the Brander and Krugman (1983) model by observing that the reciprocal dumping outcome resembles a prisoners' dilemma problem. They argue that if both countries adopt antidumping law then both countries' welfare will simultaneously increase by eliminating price discrimination globally. The authors conjecture that the spread of antidumping laws worldwide could be seen as a cooperative agreement on the part of governments to avoid the prisoner's dilemma problem. 
asymmetry in the adjustment of export prices and domestic production costs and consequently the firm will cyclically sell below costs.

Finally, there are a couple papers that show how learning-by-doing effects can lead to behavior considered to be dumping. Gruenspecht (1988) considers firms where current output level affects future production costs. This induces domestic and foreign firms to set prices below current costs to gain volume (or what he calls "experience"). Gruenspecht is one of the first to demonstrate that antidumping rules change market outcomes even when they do not appear to be binding ex post. A related explanation for dumping is found in Clarida (1993) who combines a Ricardian model of trade with a model of entry and selection.

Production efficiency varies across countries, but there is scope for technological improvement. In Clarida's model a firm can only acquire technical know-how by producing (i.e., exporting). Given the information assumptions, he shows that high cost foreign firms may export below their cost of production. In the long run the high cost firms will exit, but dumping will be observed in the short run.

\section{ii) Dumping induced by $A D$ laws}

While the initial motivation for $\mathrm{AD}$ laws was to address the concern that firms were trying to monopolize markets through predatory pricing, a number of papers have established that AD laws may ironically help facilitate collusion, encouraging firms to use AD laws strategically. ${ }^{18}$ Staiger and Wolak (1989), Prusa (1992), Panagariya and Gupta (1998), Veugelers and Vandenbussche (1999), Zanardi (2004b), and

\footnotetext{
${ }^{18}$ Hartigan (2000) argues that antidumping law with a weak injury standard undermines collusion by providing a low-cost mechanism for renegotiation (in contrast with competition law).
} 
Davies and Liebman (2006) provide models where market conditions could possibly support a cartel amongst the domestic and foreign firms and AD laws help coordinate or maintain collusion. In particular, the filing of AD cases helps to punish (or threaten punishment) to defectors in the cartel in order to support a collusive outcome. ${ }^{19}$ In addition, AD cases can even lead governments to coordinate "undertakings" or suspension agreements with the foreign firms that specify targeted minimum prices and/or quantities for imports of the investigated product. Tharakan (1991) analyzes when these undertakings are most likely in EU cases.

There is a related literature showing that foreign firms may wish to initiate $\mathrm{AD}$ cases in order to trigger other outcomes with potential positive payoffs for them. Perhaps the most well known example of this is the notion of domino dumping introduced by Anderson $(1992 ; 1993)$, where foreign firms export aggressively in order to trigger $\mathrm{AD}$ cases which, in turn, trigger a voluntary export restraint agreement that yields quota/VER rents. ${ }^{20}$ Assuming VERs allocations are related to each firm's pre-agreement market share the foreign firm's aggressive sales generate long run value.

\section{iii) Dumping when there is no dumping}

A final and very real possibility is that dumping may be found by governments even when it is not present. From the very introduction of AD laws,

\footnotetext{
${ }^{19}$ Evidence for collusion is notoriously difficult to establish, but there are a number of papers, including Prusa (1992), Taylor (2004), Zanardi (2004b), and Rutkowski (2007) that examine withdrawn AD cases as evidence of tacit collusion agreements by firms. Irwin (1998) discusses how the semiconductor disputes of the 1990s resulted in government negotiated cartel-like agreements.

${ }^{20}$ Rosendorff (1996) and Rosendorff and Milner (2001) discuss and model the implications of the high discretion in antidumping determinations.
} 
there was the worry that it simply opened another avenue to import protection.

The way government agencies decide to determine dumping and injury is flexible, allowing discretion to find dumping in almost any situation. ${ }^{21}$ Kolev and Prusa (2002) show how this discretion induces foreign firms to restrain their exports, regardless if they are actually selling below cost, a finding that harkens back to the early findings of Herander and Schwartz (1984).

Relatedly, there is evidence that explicit policy changes have made it easier for investigating authorities to make a determination of harmful dumping. Lindsey (2000) and Lindsey and Ikenson $(2002,2003)$ provide numerous examples of the ongoing weakening of the legal standards for dumping and injury in the U.S., and Blonigen (2006b) shows that changes in agency discretion has been the primary driver of increasing U.S. dumping margins. One prominent example of this is the change in the 1980s to allow the practice of cumulation, whereby all subject import sources are cumulated to determine if dumping by any one source is causing injury. Hansen and Prusa (1996) find that this legal change significantly increased the success of positive dumping determinations in the U.S., as well as the incentive to increase the number of import sources accused of dumping. Tharakan, Greenaway, and Tharakan (1998) find similar evidence for an analogous policy change in the European Union. ${ }^{22}$

In summary, there are a number of alternative reasons for why firms may engage in behavior that would lead to a finding of dumping under AD laws, from

\footnotetext{
${ }^{21}$ As we discuss below, this flexibility is likely an important reason why so many WTO disputes involve antidumping. Countries appear to have real differences over the proper interpretation of the discretion embodied in the WTO Anti-dumping Agreement.

${ }^{22}$ Gupta and Panagariya (2001) offer a free rider explanation for the empirical finding.
} 
price discrimination and below-cost-sales to excess capacity and attempts to trigger an $\mathrm{AD}$ action as a way to facilitate collusion. ${ }^{23}$ The $\mathrm{AD}$ literature has provided a number of models that theoretically underpin these explanations and shows the welfare implications of dumping and the application of $\mathrm{AD}$ measures under these various scenarios. Welfare implications (both of dumping and antidumping duties) are typically ambiguous and depend on underlying market characteristics, often the nature of competition amongst firms. Evidence for these motives is relatively sparse and determining which ones are the most common reasons for observing $\mathrm{AD}$ activity is lacking and a large empirical challenge. It remains an important topic for future research.

\section{B. When and where do AD actions and duties occur?}

\section{i) Cross-industry incidence}

One of the longest standing and most extensive strands in the antidumping literature is the empirical analysis of the cross-industry pattern of AD petitions and application of AD duties. Two key features of motivate the literature. First, AD laws provide explicit conditions under which AD duties will be applied. Second, domestic industry groups (firms, labor unions, and/or trade associations) initiate AD actions, presumably because the expected benefit for them is greater than the expected costs. These two features provide a number of hypotheses about which industries are

\footnotetext{
${ }^{23}$ Miyagiwa and Ohno (2007) argue that signaling motives can explain dumping. Cassing and To (2008) also argue that signaling is a factor in explaining whether a foreign firm will participate in the AD complaint.
} 
more likely to file and when they are more likely to be successful in getting favorable decisions by government agencies. An important focus in the literature is the extent to which "economic" factors related to the criteria for when AD duties can be applied drive the incidence of AD activity versus "political" factors that would affect whether the industry can overcome collective action issues in order to file a petition, or whether political influence by key legislators to make a positive determination in a case is more likely.

The seminal paper in this literature is Finger, Hall, and Nelson (1982), but this has been followed by dozens of works that have brought increasingly more data and refined hypotheses to bear on this question. ${ }^{24}$ In general, these studies find evidence for both economic and political factors in the pattern of AD filings and ultimate duties. On the economic side, measures of sizeable (and increased) import penetration, as well as recent poor performance by firms in the domestic industry, are significantly correlated with a higher likelihood of AD activity. Such evidence is consistent with the empirical relationships that government agencies evaluate in determining whether these is dumping and that it has been injurious to the domestic firms.

There is also evidence that political factors are important for understanding the incidence of $\mathrm{AD}$ activity across industries. Invariably, statistical evidence indicates that larger industries (especially in terms of employment) are more likely to be successful in getting $\mathrm{AD}$ duties, consistent with the notion that these industries

24 Other early pieces on this include Feinberg and Hirsch (1989), Hansen (1990), Hoekman and Leidy (1992), Moore (1992), Anderson (1993), DeVault (1993), Feinberg and Kaplan (1993), Baldwin and Steagall (1994), Lichtenberg and Tan (1994), and Sabry (2000). 
will have greater political leverage than industries representing relatively little economic activity in the economy (Baldwin, 1985).

A number of studies have found statistical evidence for political influence (or bias) in AD decisions. Hansen and Prusa $(1996,1997)$ and Moore $(1992)$ show that AD duties are more likely when filed by industries that have production facilities in the regions of key politicians, while studies by Moore (1992), DeVault (1993), and Baldwin and Steagall (1994) show that Commissioners deciding the injury test in U.S. cases differ systematically in their voting records after controlling for economic factors. $^{25}$

The fact that so many AD actions occur in just a few sectors is probably not completely accounted for in the literature. And a related question is why we don't see more antidumping filings. While this largely remains an area of research in need of additional studies, there is some evidence for a behavioral explanation. Morck, Sepanski, and Yeung (2001) and Blonigen (2006a) propose and find evidence that certain firms and industries simply learn and become more proficient over time at pursuing $\mathrm{AD}$ actions than other firms and industries.

An interesting, but sparse literature, considers possible cross-industry interdependence of AD activity. Hoekman and Leidy (1992) provide a model whereby vertical production links can lead to cascading protection as AD actions in one sector raises costs for downstream sectors and then makes $\mathrm{AD}$ actions more

\footnotetext{
25 While the majority of studies in this literature examine data on U.S. cases, analysis of EU AD cases by studies such as Tharakan (1991), Tharakan and Waelbroeck (1994a; 1994b), and Eymann and Schulknecht (1996) find very similar results.
} 
likely in the downstream sector. Feinberg and Kaplan (1993) find evidence for this in U.S. AD activity.

\section{ii) Cross-country incidence}

The substantial increase in countries adopting AD laws in the 1980s and 1990s, along with the establishment of the WTO, which began collecting data more systematically from member countries, led to a literature examining the incidence of AD activity across countries. Miranda, Torres, Ruiz (1998), Prusa (2001, 2005), and Zanardi (2004) document and assess the proliferation of countries with AD laws and resulting AD activity. Bown $(2010,2011)$ discusses more recent patterns of AD usage across countries.

Knetter and Prusa (2002) examine aggregate AD activity over time and focus on macroeconomic factors. ${ }^{26}$ Looking at AD activity by the traditional users over time, they find that periods of poor GDP growth and strong currency are positively correlated with increased country-level AD activity. In other words, macroeconomic forces (i.e., business cycles) and exchange rate movements affect filings of $\mathrm{AD}$ petitions and the likelihood of successful AD decisions. ${ }^{27}$ We note that the allegedly dumping exporting firms have no say in where a country is in the business cycle or the value of the exchange rate. Consequently, one might consider how much $\mathrm{AD}$ activity is really about economically meaningful dumping versus the need to provide protection to politically important industries.

\footnotetext{
${ }^{26}$ Leidy (1997) examines the impact changes in GDP on AD filings while Feinberg (1989) looks at the role the exchange rate trends on AD filings. Both focus just on U.S. AD filings.

27 Francois and Niels (2006) find similar evidence for Mexico. Feinberg (2005) discusses how the macroeconomic influences evolve over time.
} 
Other studies examine strategic interdependence of AD activity across countries. Maur (1998) documents the correlation in the industry usage of AD across countries, a phenomenon he calls "echoing". The steel crisis during the late 1990s/early 2000s is a stark example of echoing cases (Durling and Prusa, 2006).

Prusa and Skeath $(2002,2005)$ and Feinberg and Reynolds (2006) find evidence that countries may be engaging in tit-for-tat $\mathrm{AD}$ actions against each other. In effect, countries appear to be using the flexibility of antidumping to raise the cost of partners using AD. While the WTO does not allow for compensation for AD duties, countries appear to be able to use their own $\mathrm{AD}$ as unofficial compensation.

In contrast, Blonigen and Bown (2003) find that U.S. petitions for AD duties against foreign firms in another country are less likely when the U.S. industry has significant exports to that same foreign country, presumably because of retaliation concerns. The study also finds that the U.S. government is less likely to rule favorably on a petition for an AD duty when the named country is a WTO member who can retaliate by filing a request for dispute settlement with the WTO Dispute Settlement Body.

\section{How effective are AD actions?}

AD duties are meant to counteract harmful dumping. As a result, we should expect it to restrict imports and restore employment and profits to domestic industries that sought AD protection. Substantial evidence for these direct effects has been found 
through a number of methodologies. But the literature has also identified many important effects of $\mathrm{AD}$ actions that are more indirect and often unintended.

\section{i) Direct effects}

A traditional way to estimate the effects of $\mathrm{AD}$ duties is through computable partial or general equilibrium models, and examples of their application to AD activity include Murray and Rouslang (1989), U.S. International Trade Commission (1995), DeVault (1996a), Morkre and Kelly (1998), and Gallaway, Blonigen, and Flynn (1999). All the classical predictions are typically found by these models, with significantly lower imports; higher domestic output, employment, and profits; and overall net welfare losses. The results from these models indicate that AD imposes as large (or larger) welfare costs than any other current commercial policy.

Analysis of trade policies in computable equilibrium models is useful, particularly for providing a large range of results and the ability to estimate aggregate statistics (e.g., net welfare estimates), but also has well known issues. First, these models make functional form assumptions about the nature of demand, market competition, and costs, which can largely dictate the direction of impacts that will be found. ${ }^{28}$ They also rely on a number of parameters, such as demand elasticities, that have to be assumed or drawn from existing estimates in the literature.

\footnotetext{
${ }^{28}$ A particular concern is the typical assumption of perfect competition, since theoretical work by Dixit (1988) and Reitzes (1993) point out that welfare effects of AD duties are quite sensitive to the form of market competition; for example, quantity versus price setting behavior in an oligopoly setting.
} 
An alternative approach is statistical analysis. While such analyses are typically more targeted on a particular outcome variable, they have a better ability to estimate the magnitude of the responses of the outcome variable and how various factors affect the response. One group of early statistical studies of the direct effects of AD actions examines product-level trade data, and includes Krupp (1994), Krupp and Pollard (1996), and Brenton (2001). These papers confirm that AD actions restrict trade, but they also find that the effects on imports vary during the $\mathrm{AD}$ investigation and with the type of outcomes (e.g., AD duties versus withdrawn or suspended cases).

A number of other statistical studies, including Hartigan, Kamma, and Perry (1989), Mahdavi and Bhagwati (1994), Hughes, Lenway and Rayburn (1997), and Blonigen, Tomlin, and Wilson (2004) use event study methodology to assess the effect of AD activity on firms' stock market returns - a measure of a firm's current and expected profitability. These studies find that $\mathrm{AD}$ actions can, but do not necessarily, lead to greater profitability for the petitioning domestic firms. For example, Hartigan, Kamma, and Perry (1989) find that AD decisions do not help domestic firms when the agencies rule that there has been actual injury to the domestic firms from the dumped imports, as opposed to when they only find that there is a threat. Blonigen, Tomlin, and Wilson (2004) show that positive gains only occur for domestic firms when the foreign firms are not able to tariff jump the AD duty and locate production in the domestic market. This is a clear example where an indirect/unintended effect of $\mathrm{AD}$ actions (here, tariff-jumping) can impact the effectiveness of $\mathrm{AD}$ actions. We discuss these indirect effects next. 


\section{ii) Indirect and/or unintended consequences}

There is a fairly large set of studies documenting both the direct effect of AD duties on subject countries and also the indirect effect on non-subject countries. Perhaps the most widely discussed indirect consequence of $\mathrm{AD}$ actions is trade diversion, where imports from country sources not named in an AD petition (and, thus, not subject to the AD duty) go up substantially with the imposition of an AD duty. While Staiger and Wolak (1994) discuss non-subject suppliers, Prusa (1997) was the first to emphasize and document the phenomenon. Using trade data for U.S. AD cases initiated from 1980 through 1988, Prusa finds that in some cases trade diversion was so large that even though the AD duty reduced imports from the named countries (the direct effect), total import volumes could actually increase after an $\mathrm{AD}$ activity. As a result, the direct effect of the AD duty on imports is largely, if not completely, mitigated by the indirect effect - trade diversion.

As documented in Table 7 there is a fairly robust set of findings on this issue. Staiger and Wolak (1994) primary focus on investigation effects and estimate that half the reduction of trade occurs during the period of investigation. They also find that the mere filing of an antidumping petition leads to a decrease in imports and increase in domestic production. They conclude that the value of protection during the period of investigation could well make it worthwhile for an industry to initiate an investigation even if the case is ultimately rejected. Staiger and Wolak also find that domestic production increases when authorities rule that dumping is taking place, but never impose a duty due to some type of settlement agreement. 
Prusa (2001) and Carter and Gunning-Trant (2010) use the Arellano and Bond technique to estimate a dynamic model for panel data to estimate the trade effects for U.S. AD actions. Prusa's analysis focuses exclusively on manufacturing industries while Carter and Gunning-Trant concentrate on agricultural products. The results are broadly consistent - both report large reductions in subject supply and significant trade diversion.

There are also a series of studies involving EU AD actions. While Lasagni (2000) finds trade effects for the EU on the order of those found for the U.S., he also documents that the trade effects associated with price undertakings are considerably smaller than those associated with duties. This perhaps explains why subject countries often seek to negotiate undertakings with the EU. Konings, Vandenbussche, and Springael (2001) use the Arellano and Bond GMM estimation approach and find substantially smaller trade effects - both direct and indirect than those found for the U.S. More work is certainly warranted examining why the trade effects differ so considerably between the EU and U.S. In general, subsequent studies have found these trade diversion impacts to be a quite general phenomenon across many countries/regions with AD policies, including Mexico (Niels, 2003), India (Ganguli, 2008), and China (Park, 2009).

As mentioned earlier, another indirect effect that can substantially mitigate direct effects of $\mathrm{AD}$ actions is tariff-jumping. The domestic industry may experience little protection if foreign firms can easily avoid the AD duties by locating production in the domestic market. Haaland and Wooton (1998), Blonigen and Ohno (1998), and Belderbos, Vandenbussche, and Veugelers (2004) are theoretical 
studies that examine the various factors that can trigger such AD-jumping behavior in a number of game theoretic situations. A number of empirical studies have examined the extent to which tariff-jumping actually occurs after AD investigations and/or duties, including Belderbos (1997), Blonigen (2002), and Girma, Greenaway, and Wakelin (2002). While they find that some tariff-jumping occurs in response to AD duties, it is fairly modest, as only large firms from developed countries seem to be able to avail themselves of this strategy. As mentioned earlier, Blonigen, Tomlin, and Wilson (2004) find that tariff-jumping FDI significantly reduces profits of domestic firms that petitioned for AD protection.

Far and away the largest set of unintended consequences documented in the literature stem from the unique way in which $\mathrm{AD}$ initiations and measures are administered. This has been the subject of many papers in the literature, which we discuss next.

\section{$D$. How do administrative, legal, and regulatory processes affect $A D$ laws and their consequences?}

As described in section II.B, administration of AD laws involves a fairly involved bureaucratic process to implement decisions based on criteria that can be broadly interpreted (e.g., what constitutes "injury"?) and are not obvious how to apply in practice. As a result, the process gives significant discretion to the administrators and can induce strategic behavior by firms. Additionally, legislation can alter the process over time. 
The literature has shown a range of ways in which firms may distort their behavior in order to manipulate a possible AD investigation. For example, papers such as Fischer (1992), Prusa (1994) and Kohler and Moore (2002) provide theoretical models where domestic firms will manipulate their output and pricing to more likely satisfy the injury and dumping criteria in an $\mathrm{AD}$ investigation, while foreign firms will analogously distort prices and production to lessen the chance of getting an $\mathrm{AD}$ measure applied to their exports. As mentioned in section IV, the presence of $\mathrm{AD}$ laws may also cause exporting firms to do such things as keep their production capacity lower (Staiger and Wolak, 1992) to avoid dumping of excess products in periods of low domestic demand, or price higher than they otherwise would to help support collusion.

$\mathrm{AD}$ duties are unusual because there are procedures whereby the duty can be reviewed after it has been applied and adjusted based on the foreign firms' pricing decisions. This is a prominent a feature of the U.S.'s implementation where the current duty margin is an "estimate" of the final margin. ${ }^{29}$ The actual margin will be determined at the end of the year..$^{30}$ Blonigen and Park (2004) show that periodic review of $\mathrm{AD}$ duties after their application creates a dynamic pricing problem for any firm exporting to a market with AD laws. They provide theory and evidence that firms alter their price to an export market with AD laws based on the expected probability of the application of an $\mathrm{AD}$ duty, as well as how a firm would optimally

\footnotetext{
${ }^{29}$ While no other country uses the retrospective assessment system, every county has provisions that allow it to reassess the dumping margin.

${ }^{30}$ We note that while in theory every U.S. AD margin should be revalued each year, in practice this does not happen. Rather, in many cases neither the foreign supplier nor the domestic industry seeks a reassessment and consequently the estimated duty becomes the actual margin for that year.
} 
adjust its prices over time once an AD duty is applied. Blonigen and Haynes (2002) relatedly show how firms' pass-through of exchange rates and AD duty itself are affected by administrative reviews after the AD duty is in place. ${ }^{31}$

The involved process surrounding AD investigations and decisions means that there are substantial costs to petition for an AD duty that decrease for those who are experienced with the process. Based on this, a few studies have hypothesized and found evidence that certain firms and industries can become more habitual users of the AD process. Morck, Yeung, and Sepanski (2001) find evidence for this with steel firms in the U.S., while Blonigen (2006a) finds evidence across all U.S. AD cases that prior experience with filing AD cases increase the probability that a firm will file a case in the future. These findings may be part of the explanation for why we see AD activity concentrated in only certain sectors.

Complicated bureaucratic processes are susceptible to agency capture and distortion of processes at the discretion of the bureaucrats. As discussed above there is evidence that political factors affect AD decisions. While AD decisions are supposed to emerge from an administrative process that simply verifies if the economic/accounting criteria (dumping and injury) are satisfied, studies have found that political influence affects the determinations. A few studies examine casespecific data in the U.S. of dumping margin calculations, which are conducted by a division of the U.S. Department of Commerce, including Blonigen (2006b) and Moore (2006b). They find that rules for estimating dumping has evolved over time (at the behest of domestic industries), especially the rules to disallow information

31 Related to the issue of duty adjustment and payment, Gupta (1999) examines the question of why firms pay the duty rather than raising their export prices. 
provided by the foreign firms, leading to substantial increases in U.S. dumping margins and resulting $\mathrm{AD}$ duties over time.

Additionally, politicians can get directly involved in affecting the AD administrative process through legislation. Hansen and Prusa (1996) and Prusa (1998) document how a legal change allowing AD agencies to cumulate the effect of all investigated import sources when determining injury (rather than examine each investigated source individually) significantly increased the number of import sources named in investigations and, more importantly, the likelihood of an injury finding. Tharakan, Greenaway, and Tharakan (1998) find similar evidence for an analogous legal change in the European Union.

More recently, the U.S. saw a legal change called the Byrd Amendment, which allowed for a mechanism to provide the collected AD duties directly to the firms who petition for the AD duties. Ultimately rescinded after it was found inconsistent with the WTO, a number of studies analyzed the distorting impacts of the law, including Collie and Vandenbussche (2006), Evenett (2006), and Ogawa and Ono (2011). Empirically, Liebman and Reynolds (2006) find that firms subsequently using AD laws and receiving Byrd payments provided political contributions to key legislators. Reynolds (2006) finds evidence that the Byrd Amendment increased AD petitions, as well as the average number of domestic firms participating in the petitions.

The large amount of discretion in the determination of antidumping remedies is the source of considerable international tension. Often countries subject to $\mathrm{AD}$ duties feel the measures are unwarranted and that the $\mathrm{AD}$ using 
country did not follow the WTO rules. Under the GATT/WTO members can file disputes challenging a country's practices. While there was a dispute system preUruguay Round, compliance was a key failing of the old system; GATT contracting countries either blocked or simply ignored the findings of GATT Panels. ${ }^{32}$ One of the Uruguay Round's more notable achievements was the establishment of the WTO Dispute Settlement Understanding (DSU).

AD has emerged as the most frequently disputed policy by far. Bown (2009) estimates that more than $30 \%$ of the entire WTO dispute initiation caseload involved challenges to either antidumping or countervailing duties. Given that AD disputes are far less likely to be resolved via consultations, AD's share of actual Panel and Appellate Body time is considerably higher. AD disputes often involve technical and legal aspects of the law, but often important insights into economic consequences of $\mathrm{AD}$ can be gleaned from the disputes.

One entry point into this literature are papers connected to a project by the American Law Institute bringing well-known economics and legal scholars to jointly discuss cases brought to the WTO, many of which involve AD issues (see Table 1). Traditionally trade lawyers have focused on the relationship between AD laws and antitrust and competition laws (e.g., Victor, 1982; Applebaum and Grace, 1987; Hoekman and Mavroidis, 1994; Sykes and Cooper, 1998). By contrast, the American Law Institute program has shown there is a far broader set of AD related issues that

\footnotetext{
32 The need to produce consensus also affected how Panels constructed their rulings as the three panelists knew that their report had also to be accepted by the losing party in order to be adopted. Accordingly, there was an incentive to rule not solely on the basis of the legal merits of a complaint, but to aim for a "diplomatic" solution by crafting a compromise that would be acceptable to both sides.
} 
benefit from the perspective of economists, including the costs of disputes (Tarullo, 2002), the incidence of WTO disputes (Bown, 2005), the relevance of predatory intent (Howse and Staiger, 2005), and zeroing and the biased nature of "fair" comparison (Bown and Sykes, 2008; Prusa and Vermulst, 2009).

\section{Recent Research Developments}

Research on AD has continued to evolve, and the recent literature has both extended the prior literature and taken it in new directions. Much of the recent literature is responding to how $\mathrm{AD}$ activity and its role in world trade policy has evolved. AD has continued to be the most frequently used contingent trade policy instrument (Bown, 2010, 2011). But who uses AD has changed a lot, as there has been a decrease in $\mathrm{AD}$ activity by traditional users and a marked increase in use by new users (primarily developing countries). At the same time there has been a rise in preferential trade agreements (PTAs) and the maturation of the dispute resolution process in the WTO, both of which have the potential to affect AD use. Finally, the rise of new firm- and plant-level data has provided researchers the opportunity to examine the effect of ADs with much more precision than before.

\section{A. Measuring the Myriad Effects of AD Duties on Trade}

\section{i) Does AD Distort Trade in Third Markets?}

In an important paper, Bown and Crowley (2007) document that the trade effects of AD protection spill over to other markets. They consider a model with 
multiple countries. Bown and Crowley argue there are at least four distinct effects of AD duties. First, there is the direct effect on subject exporters. An AD duty imposed by country $m$ on supplier $x$ will result in less supply from $x$ to $m$. Second, the duty on $x$ will often lead other suppliers (county $y$ ) to increase supply to the AD using country $(m)$. Bown and Crowley dub these effects trade destruction and trade diversion. Both of these trade effects have been robustly documented in the previous literature (see Table 7). ${ }^{33}$

Bown and Crowley also argue that an AD duty might lead to two other indirect effects. After the AD duty is imposed by country $m$ on $x$, country $x$ may increase its shipments to third markets (say, countries $y$ and $z$ ). They call this effect trade deflection. Along the same vein, Bown and Crowley also argue that if $m$ were to impose an AD duty on exports from a third country (w), this will cause $x$ to export less to that third market. They call this trade depression.

Using detailed data on Japanese exports Bown and Crowley find strong statistical evidence for all effects. Of particular note, they document that U.S. AD duties against Japan leads to a 5-7\% increase in Japanese exports of the same product to the average third country market (trade deflection). ${ }^{34}$ They also find that the imposition of a U.S. antidumping measure against a third country depresses Japanese trade, as the average U.S. duty imposed on a third country leads to a 5-19\%

\footnotetext{
33 Hillberry and McCalman (2011) offer an interesting study of what happens within the AD-using country in advance of the petition. They find very little evidence of aggregate import surges or of large reductions of import prices. Instead, they argue the main issue is market share growth of (eventual) subject countries at the expense of non-subject suppliers. If this is indeed the case, it provides confirmation for substantial diversion documented in Prusa $(1997,2001)$ - non-subject suppliers are ready and willing to fill the void.

${ }^{34}$ Durling and Prusa (2006) find similar patterns for a particular product, hot-rolled steel.
} 
decrease in Japanese exports of that same product to the average third country's market (trade depression). ${ }^{35}$

A couple recent papers also document unusual trade-distorting effects of AD laws by examining specific markets. In an interesting twist on the usual trade diversion analysis, Baylis and Perloff (2010) document how the product-specific nature of an $\mathrm{AD}$ order can create unexpected incentives to product shift. They analyze the suspension agreement that emerged from the U.S. AD investigation on fresh tomatoes from Mexico. They find that the agreement caused Mexico to ship more tomatoes to Canada (trade deflection) and Canada to ship more tomatoes to the U.S. (trade diversion). Overall, they estimate that $80 \%$ of the direct effect was offset by the indirect trade effects. In addition, because the agreement only covered fresh tomatoes, Baylis and Perloff document a significant increase in Mexican shipment of tomato paste to the U.S.; i.e., trade diversion involving a related product. Cohen-Meidan (2013) examines the impact of the U.S. imposition of AD duties on Japanese and Mexican imports of Portland cement in the early 1990s, and finds heterogeneous trade and market impacts within the U.S. market. The large transportation costs create a regionally segmented market that significantly affects both the pattern of trade and also the impact of trade policy. She finds pronounced regional variation in the impact on domestic prices, sales and imports. Specifically, she finds AD duties cause significant price and production effects, but these effects

\footnotetext{
35 Bown and Crowley (2006) extends these findings by focusing specifically on the trade diversion and deflection associated with the U.S. use of AD on the EU market. They find that U.S. AD duties impose terms-of-trade externalities on the EU as U.S. duties on Japanese exports are associated with substantially lower Japanese export prices in the EU market.
} 
are highly localized (i.e., West Coast, Gulf Coast) and had little impact on more distant U.S. markets.

\section{ii) What are the Firm- and Plant-level Impacts of AD Duties?}

The increased availability of firm- and plant-level data has touched virtually all areas of research in international economics, and the literature on AD is no different. Several important papers study AD effects using firm- and plant-level data from a number of countries, including the U.S., the EU, and China. The studies demonstrate that $\mathrm{AD}$ is an excellent commercial policy for testing the predictions of the models of trade with heterogeneous firms.

Pierce (2011) studies the effect of AD on the performance and behavior of U.S. manufacturers. He finds that while AD protection raises the revenue for importcompeting firms, the increase in revenue associated with $\mathrm{AD}$ duties is primarily due to increases in prices and mark-ups, as physical productivity falls among protected plants. Moreover, he finds AD duties slow the reallocation of resources from less productive to more productive plants.

Similar studies have been conducted on the effect of AD on EU firms. Konings and Vandenbussche (2005) use a large panel dataset of EU firms and estimate markups before and after the filing of an $\mathrm{AD}$ case. Their findings indicate that $\mathrm{AD}$ protection has positive and significant effects on domestic mark-ups except in cases where there is a large volume of import diversion. Konings and Vandenbussche (2008) use the same dataset to study the effect of AD protection on the productivity of EU firms in import-competing industries. Their results reinforce those in Pierce 
(2011). Namely, they find that the productivity of the average domestic firm improves during AD protection. Yet, the average hides important differences across firms. They find firms with relatively low initial productivity have productivity gains during $\mathrm{AD}$ protection, while firms with high initial productivity experience productivity losses. This finding is consistent with the theories of trade liberalization and the response by heterogeneous firms. Put bluntly, AD protection appears to be good for bad firms, but bad for good firms.

There are also important studies of the effect of AD on exporters. Chandra and Long (2013) use detailed Chinese firm level data and find U.S. AD duties decrease labor productivity and TFP of targeted Chinese firms. They find that Chinese firms with the highest initial export intensity experience the biggest drop in productivity due to the U.S. AD duties. From a welfare perspective, this suggests AD is a costly policy.

Lu, Tao, and Zhang (2013) use monthly transaction level Chinese customs data to study how Chinese exporters respond to U.S. AD protection. They find that $\mathrm{AD}$ protection causes a significant decrease in the total export volume. Interestingly, they find that the fall in exports is due to a significant decrease in the number of exporters (i.e., extensive margin effects). Moreover, they find that the firms who exit the export market are largely among the less productive firms.

Brambilla, Porto, and Tarozzi (2012) go one step beyond standard plant- and firm-level analyses and offer an important study of AD duties on individual households in the exporting country. In 2003, the U.S. imposed large AD duties on imports of catfish from Vietnam. These duties resulted in a sharp decline in 
Vietnamese exports of catfish to the U.S. What makes this a particularly interesting study is that Vietnamese catfish production is dominated by household-level production. Using a unique panel dataset of Vietnamese households, they document the responses of catfish producers (i.e., households) in the Mekong delta between 2002 and 2004. They find the AD order significantly lowered the income growth for catfish farmers.

\section{iii) Does Antidumping Have a Chilling Effect on Trade Beyond the Targeted Products?}

Economists have long debated the breadth or extent of AD protection. As we discussed above, the best estimates of the direct trade effect of AD protection are on the order of 3-8\% of a country's total imports, with most users having a far lower percent of their imports covered (Bown, 2011). One could argue, then, that even if $\mathrm{AD}$ is the largest and most frequently used contingent trade remedy (and the mostly costly single commercial policy), AD may nonetheless be a desirable policy as it serves an important role in promoting overall trade liberalization by acting as a pressure release valve (Feinberg and Reynolds, 2007; Martin and Vergote, 2008; Moore and Zanardi, 2009, 2011). In effect, the ability to provide trade relief for political sensitive industries makes broad tariff concessions easier to negotiate. The deadweight losses in a small number of industries could be small compared to the overall gains contained in a trade agreement. Consequently, one could argue the value of $\mathrm{AD}$ exceeds the costs it imposes on an economy. At the same time, however, it may be the case that the direct effects understate the true distortion caused by AD. The specter of AD duties could reduce trade in products that are at risk of being 
subject to an $\mathrm{AD}$ order. That is, the use of $\mathrm{AD}$ on one set of products from a country may discourage the export of other products from the same country. This spillover effect is sometimes referred to as the "chilling effect" of AD on overall trade.

Two related papers examine this issue and come to strikingly different conclusions. Egger and Nelson (2011) estimate a gravity model using a panel dataset of bilateral trade for nearly all AD users and targets over the period 19602001. They use a structural approach in the style of Anderson and van Wincoop (2003) to evaluate the spillover issue. They find that the spillover volume and welfare effects are indeed negative, but that the estimates are quite modest. They conclude that AD may be much ado about nothing.

Vandenbussche and Zanardi (2010) also estimate a gravity model using a large panel dataset of bilateral trade flows. In contrast with Egger and Nelson (2011), they focus on new users of antidumping. They find "tough" new users (India, Mexico, Brazil, Taiwan, etc.) experience a large chilling of their aggregate imports and conclude that the dampening effects of AD laws on trade flows substantially offset the increase in trade volumes derived from trade liberalization. Far from being unimportant, they conclude that $\mathrm{AD}$ erodes the value of hard-won trade concessions.

In an attempt to resolve this discrepancy between the two papers, Vandenbussche and Zanardi also estimate their model using a larger set of countries (similar to the countries used by Egger and Nelson). They find the estimated effect falls significantly with this wider sample. This suggests the spillover effect is 
predominately a concern for new and tough users - but these are exactly the countries where the value of tariff concessions should be large.

\section{iv) Does Antidumping Result in Exit?}

Given the important role sunk costs are believed to play in modern trade theories and given the size of the average $\mathrm{AD}$ duty, the question of whether $\mathrm{AD}$ protection results in firms/countries to exit a market arises. If $\mathrm{AD}$ results in a firm to cease supplying a market, the costs of $\mathrm{AD}$ protection may well be larger than what is implied by the reduction in trade. Besedes and Prusa (2013) examine this issue and find that $\mathrm{AD}$ investigations often drive export suppliers entirely out of the market. Using monthly disaggregated trade data along with U.S. AD case information, they estimate a hazard model and find that $\mathrm{AD}$ increases the likelihood of exit by more than 50 percent. Reminiscent of Staiger and Wolak (1994), they find large effects during the investigation period - in many cases subject firms exit from the U.S. market while the investigation is in process. In contrast with the earlier finding, they find large trade effects (exit) even before the preliminary duties are in place. Moreover, they find that re-entry to the AD using market is less likely the longer the AD duty is in effect.

\section{B. Does Antidumping Matter for Developing Countries?}

Until quite recently nearly all empirical studies have focused on the use of AD by traditional users. As mentioned, the new users have become both the major users and also the major targets of AD protection in the past couple decades. Cheong 
(2007) examines the EU's use of AD and finds that the EU has increasingly begun to use AD against countries with lower per-capita income and has imposed more restrictive measures on them (than on comparable cases against developed countries). He does not find any support for the Blonigen and Bown (2003) retaliation capacity hypothesis - the EU is just as likely to target developing countries with or without their own AD statute. However, he does find support for the Prusa and Teh (2010) PTA effect - that is, developing countries in PTAs with the EU are less likely to be subject to EU AD actions.

Bown and Crowley (2014) extend the analysis of Knetter and Prusa (2002) to emerging economies. They find evidence of a counter-cyclical relationship between macroeconomic shocks and new $\mathrm{AD}$ restrictions as well as an important role for fluctuations in bilateral real exchange rates with the estimates growing over time. ${ }^{36}$

Bown and Tovar (2011) use Indian product-level data to examine whether countries use AD to reverse commitments to lower tariffs. They present compelling evidence that India unwound its commitment to reduce tariffs through use of AD (and safeguard protection) in the face of political-economic pressure.

Bown (2013) focuses on the use of AD by developing countries. In contrast with the modest increase in administered protection by traditional AD users during the 2007-09 economic crisis, Bown finds a marked increase in protection by developing countries. He provides several alternative measures of the increase, but, on average, it appears that $\mathrm{AD}$ use by developing countries increased about five times more than by developed countries. One explanation is simply that developing

36 Bown and Crowley (2013) apply a similar model to traditional users and focus on the model's predictions for the post-financial crisis period. 
countries' "demand for protection" is more sensitive to to economic conditions. But, the difference in elasticity is one part of the story. There are several additional factors that explain the sharp increase in AD protection. First, Bown notes the developing countries have lowered tariffs over the past decade. By contrast, there have been few tariff reductions by developed countries. This liberalization has been an additional motivation for developing countries to use AD protection. Second, much of the increased trade and most of the increased AD activity has involved emerging country-emerging country pairs. The targets' relative inexperience in defending themselves in $\mathrm{AD}$ proceedings has made them easy prey. Overall, Bown finds that most of the new $\mathrm{AD}$ activity is initiated by developing countries targeting other developing countries. Further explorations of South-South protection are an important area for future research.

\section{Is AD Used Strategically at the Country Level?}

There is a long and ongoing debate about the extent to which countries use AD strategically, with a significant amount of research on this recently. Bao and Qiu (2011) explore whether China's AD is more retaliatory than that of the U.S. They find support that both countries usage is consistent with a tit-for-tat incentive, but find no evidence that China is more retaliatory.

Feinberg and Reynolds (2008) examine whether U.S. exporters are subject to more $\mathrm{AD}$ actions as a result of the U.S. import-competing industries use of AD. After controlling for macroeconomic and exchange rates, they find retaliation playing a 
larger role in a country's decision to file AD actions against the United States compared to other target countries.

Miyagiwa, Song, and Vandenbussche (2010) argue that a country's relative size plays a role in the strategic decision to retaliate. If all countries are the same size, then a retaliation-driven "trade war" makes all parties worse off. Thus, for comparably-sized countries AD wars may be averted. However, when the foreign market is relatively small, then $\mathrm{AD}$ retaliation has a modest effect on the larger country. They argue that their model is consistent with the growing proportion of AD disputes between countries of vastly different economic size.

The question of why countries retaliate has been long debated. Why would a country deviate from the cooperative low tariff equilibrium? Martin and Vergote (2008) analyze the role of retaliation in trade agreements and argue that AD is not a deviation from a cooperative equilibrium, but rather a crucial part of the equilibrium. They show that, in the presence of private information, retaliation can be used to increase the welfare derived from trade agreements. Specifically, because governments cannot resort to international transfers or export subsidies to compensate for terms-of-trade externalities, retaliation is a necessary feature of any efficient equilibrium. From this perspective, the benefit from AD is hard to directly measure, but essential under existing WTO rules. 


\section{Trade Agreements, the WTO, and AD}

\section{i. Do PTAs Affect the Patterns of AD Use?}

It is well known that preferential tariffs discriminate against non-members it is not clear whether other PTA policies accentuate or attenuate this discrimination. Prusa and Teh (2010) focus on the extent to which PTAs alter the pattern of AD. AD is a particularly apt policy to study because there is considerable variation in AD rules across PTAs. Some PTAs contain no AD provisions, some prohibit its use, and others contain special rules for its use. They find PTAs have had large effect on the pattern of $\mathrm{AD}$ use: decreasing the incidence against PTA members and increasing the number of AD actions against non-PTA members. The results are particularly strong for PTAs that have additional AD rules. Taking the two effects together, they find net effect of PTA rules on total AD filings is small. Bown (2014b) finds a similar effect looking just at PTAs involving Turkey.

\section{ii. Has Mandatory Sunset Worked?}

One of the major changes to AD rules during the Uruguay Round of the GATT was the inclusion of a mandatory sunset provision. Previously, there was no automatic review of $\mathrm{AD}$ orders and, in theory, an $\mathrm{AD}$ duty could be in place forever. This was not merely a theoretical possibility as there were a AD duties that had been in place since the 1960s. 
Several authors have studied how sunset reviews have worked in practice. Moore (1999) and Gourlay and Reynolds (2012) examine sunset decision making at the U.S. Department of Commerce. They both find that the vagueness of the WTO rules regarding sunset reviews have allowed Department of Commerce to rule that dumping would resume at the levels determined at the original investigation regardless of how many years have passed and regardless of how many administrative views have taken place (DeVault, 1996b). Liebman (2004) and Moore (2006a) examine the injury test during sunset reviews and find, similar to the earlier literature on original investigations, both economic and political factors play a role. Overall, there is little evidence that the mandatory sunset provision actually shortens the duration of duties. In fact, Prusa (2011) finds that for the U.S., $\mathrm{AD}$ duties are longer lived after the sunset provision was enacted then under the earlier rules.

\section{iii. Is the WTO Constraining the Use of AD?}

As mentioned above the WTO DSU is one of the major achievements of the Uruguay Round and AD has emerged as by far the most frequently disputed policies. Many of the $\mathrm{AD}$ disputes involve the methods for calculating $\mathrm{AD}$ margins. The single most common issue challenged to the WTO is the U.S. practice of "zeroing" in the calculation of dumping. Zeroing is a somewhat obscure technical issue related to the calculation of $\mathrm{AD}$ margins where all negative dumping amounts are replaced with a zero prior to the calculation of the final dumping margin. As a result, this discretionary practice will lead the U.S. to find larger dumping margins by virtually 
any foreign firm it investigates. ${ }^{37}$ Bown and Prusa (2011) estimate that approximately $25 \%$ of current U.S. antidumping cases would have resulted in a finding of "no dumping" if zeroing were not used.

According to Bown and Prusa (2011) through the first 15 years of the Uruguay Round zeroing had been the subject of more than $13 \%$ of WTO Panel investigations and almost 20\% of WTO Appellate Body reports. They conclude that the WTO AB had likely devoted more time to zeroing than any other single issue in the WTO. ${ }^{38}$ If nothing else, the numerous disputes involving zeroing highlight a weaknesses of the WTO DSU. Since each dispute will require at least 18 months to adjudicate and since WTO "relief" is only prospective, WTO members have fairly weak incentives to change their rules. For instance, the U.S. is still zeroing some 15 years after the WTO first ruled that zeroing was WTO inconsistent.

For U.S. trading partners, the U.S.'s non-responsiveness to the zeroing decisions sends a signal that compliance is voluntary, and this effectively erodes the legitimacy of the WTO. As evidence, in the last several years there have been five separate disputes involving a set of similar antidumping practices by China and in each case the WTO has ruled against China's procedures. As of the time of this writing, China has not revised any of its procedures in response to the WTO's dispute body determinations.

\footnotetext{
${ }^{37}$ Relatedly, Blonigen (2006b) finds that discretionary practices by U.S. agencies is the main reason why dumping margins in U.S. cases have risen from 15\% to 60\% over the 1980 to 2000 period.

38 There have been numerous papers studying zeroing and its effects, including Janow and Staiger (2003), Bown and Sykes (2008), and Prusa and Vermulst, $(2009,2011)$.
} 


\section{Concluding Comments}

The landscape of AD use has been significantly evolving over the past decade, opening up a number of important new phenomena for analyses. The construction and maintenance of the Global Antidumping Database provides a rich, detailed dataset for researchers. We now have information on $\mathrm{AD}$ actions that goes back decades and now covers virtually all countries using AD laws. We believe there are many fruitful avenues to use this rich data as a starting point to not only re-visit and test existing theories and hypotheses about $\mathrm{AD}$, but also the general effects of trade policy. We also think there are opportunities to not only extend theory in the literature, but also test existing theories we have, especially those related to the motivation for dumping and the role of $\mathrm{AD}$ in the structure of multilateral trade liberalization. ${ }^{39}$

The main developments in $\mathrm{AD}$ use over the past decades have been the major targeting of China and the substantial rise of non-traditional users, particularly the BRIC countries (Brazil, Russia, India, and China). The rapid integration of China into the world trading economy, including the accession into the WTO in 2001 with the concomitant liberalization of many standard forms of trade protection vis-à-vis China, has clearly led to trade frictions on many fronts and is a likely reason why China has been an overwhelming target of AD activity. Beyond this general observation, however, little has been done to formally examine the AD response to this natural experiment- the opening of the world to trade with China. What has

\footnotetext{
39 Please see chapters 9 and 10 of this Handbook for more on the theory of the potential role played by various forms of contingent protection within multilateral trading agreements.
} 
been the cross-industry and cross-country incidence of AD use against China and does it accord with theory? What has Chinese trade looked like for countries with AD laws versus those without? And to what extent has the rise of other nontraditional users been a response?

$\mathrm{AD}$ activity by non-traditional users clearly requires further analysis as well, especially given their rapid rise in use, which has now surpassed that of traditional users and appears to be increasing in intensity. What we know empirically about $\mathrm{AD}$ from the prior literature comes almost exclusively from analysis of $\mathrm{EU}$, and especially, U.S. data. But the non-traditional users have different economic structures, different political economy forces, and are positioned differently in the global economy than the EU or U.S. As a result, the motivations for and the economic outcomes of AD activity are likely quite different as well. While an interesting recent development in EU and U.S. AD activity is their disputes over technical issues of AD implementation in the WTO dispute settlement process, nontraditional users are not very involved in these processes and seem to follow simpler (though often less well-documented) methods to apply AD remedies. This might suggest that there is a life cycle of AD use as countries mature in their use and sophistication of the law over time, or could alternatively indicate that use of $\mathrm{AD}$ laws depends on the level of economic development of the country. ${ }^{40}$

There are number of areas where we feel that the AD literature would benefit by revisiting existing theory and testing them further, often with much richer data available than when the theories were first developed. Perhaps the most

\footnotetext{
40 We thank Chad Bown for making the observation that the traditional and non-traditional users of $\mathrm{AD}$ have these important differences in how they use AD laws.
} 
fundamental would be further empirical evaluation of the various theories for why dumping may occur. Understanding the underlying motivation for dumping is critical in determining the impact of AD remedies and their ultimate welfare effects. Yet, with the exception of only a few studies, there has been little done to determine which motivations for dumping appear to be most salient in practice. ${ }^{41}$

Another example of AD theory that should be revisited is the few early papers on vertical production relationships and AD. Hoekman and Leidy (1992) introduced the concept that $\mathrm{AD}$ actions in an upstream industry can affect $\mathrm{AD}$ activity in downstream industries and Feinberg and Kaplan (1993) followed up with some initial empirical evidence for such effects in U.S. data. These papers were published over two decades ago and there has been little to no work on the issue of vertical production relationships and $\mathrm{AD}$ since then. ${ }^{42}$ The dramatic increase in vertical specialization and global value chains in the world economy over the past couple decades makes further investigation into this issue almost an imperative for the AD literature.

The international trade literature has also developed theory and empirics around a number of new issues that the $\mathrm{AD}$ literature has often not examined, but should. One such issue is product quality. A number of recent papers develop methods to explore heterogeneity in the quality of products exported by firms,

\footnotetext{
${ }^{41}$ These studies include Taylor (2004) that examines whether U.S. withdrawn cases indicate tacit collusion by firms, and Blonigen and Wilson (2010) examining the excess capacity model. Bown and Tovar (2011) is also related in that they examine whether AD use in the wake of trade liberalization follows the Grossman and Helpman (1994) protection for sale model, but also informs the theoretical literature that sees the role of AD activity as a release valve for other trade concessions.

${ }^{42}$ A recent exception is Cohen-Meiden (2015) that examines differences in calculation of U.S. dumping margins depending on whether the foreign producer is integrated with the domestic importer or not.
} 
including Hallak (2006), Verhoogen (2008), Khandelwal (2010), Baldwin and Harrigan (2011), Topalova and Khandelwal (2011), and Kugler and Verhoogen (2012). One pattern that emerges in this literature is that exporting firms are associated with higher quality products than their domestic-oriented competitors and that trade liberalization can lead to access to higher quality products. What is the incidence of $\mathrm{AD}$ across various levels of product quality, and to what extent does it impact the quality of available products or firms' product quality decisions?

Another issue that has rarely been explored in the AD literature, but recently has received significant attention in the literature, is the idea that firms' exports to various destinations are far from stable, with lots of churning, necessary experimentation for new markets, and non-linear entry costs across and within destinations. ${ }^{43}$ The recent study by Besedes and Prusa (2013) finds that AD duties often completely eliminate the targeted export flow, and papers by Bown and Crowley (2007) and Lu, Tao and Zhang (2013) show that AD duties can cause firms to alter export destinations. But there are still many open topics in this area. For example, does $\mathrm{AD}$ activity limit firms' decisions on which export destinations to try or limit how aggressively they grow in new markets? If entry costs are lowest for nearby markets, are countries located near active $\mathrm{AD}$ export destinations ultimately limited in their ability to grow exports across all destinations?

The international economics literature has also seen the resurgence of quantitative analyses where researchers build structural, often general equilibrium, models and simulate economic experiments and counterfactuals with these models.

${ }^{43}$ Key papers here include Arkolakis (2010), Arkolakis and Muendler (2010), Besedes and Prusa (2006; 2011), Albornoz et al. (2012), and Eaton et al. (2012). 
There has been little to no type of analysis like this in the AD literature since Gallaway et al. (1999) until a recent working paper by Ruhl (2015). Both efforts focus on the welfare impacts for the import-protecting country using U.S. data and assume that the primary motive for dumping is simple price discrimination. There is certainly plenty of room for the literature to further explore various market and welfare effects on exporting countries and for alternative dumping motives (e.g., short-run excess capacity) using these quantitative approaches.

We reiterate that there are trade policy issues that the available AD data will be better able to explore than other trade policy settings and data. The obvious comparison is to the extensive literature examining large unilateral trade liberalizations reviewed in chapter 3 of this Handbook. Those settings are typically one-time political economy events. In contrast, each $\mathrm{AD}$ case is its own political economy event that is often interconnected with other AD cases, affording a much richer set of observations to evaluate political economy forces and how they evolve over time and in response to other events (e.g., trade agreements or other AD cases). Relatedly, one can study interactions of industry evolution and the demand for trade protection. As shown by the literature looking at worldwide $\mathrm{AD}$ patterns, $\mathrm{AD}$ activity in a given country may be interdependent with $\mathrm{AD}$ activity in other countries, and is not just a one-time unilateral action. Thus, one can better study these multilateral interdependencies in trade policy actions. Finally, the more targeted nature of $\mathrm{AD}$ allows one to study trade responses that one cannot with unilateral trade actions. An obvious example is the analysis of how trade diverts to other import sources that are not named in an AD action. Focusing on these issues 
where AD data is the only well-suited context for studying a general trade policy question is an obvious strategy to making substantial contributions to the literature.

But we have also indicated large important questions about AD activity itself that merit significant attention. One area, as noted above, is better analysis to understand which theories for the motivation of dumping best fit the AD cases we see. But we will also end with a puzzle that we pointed out in our last literature review (Blonigen and Prusa, 2003) that still remains. While we have shown that AD activity is substantial in our global economy, why isn't there even more AD activity? And relatedly, why is it so concentrated in only certain products? These types of remaining questions show that there is significant interesting and important work left to be done. 


\section{References}

Anderson, James E. (1992) “Domino Dumping I: Competitive Exporters”, American Economic Review 82(1):65-83.

Anderson, James E. (1993) “Domino Dumping II: Anti-dumping”, Journal of International Economics 35(1-2):133-50.

Anderson, James E. and VanWincoop, E. (2003). “Gravity with gravitas: A solution to the border puzzle", American Economic Review 93(1): 170-92.

Anderson, Keith B. (1993) "Agency Discretion or Statutory Direction: Decision Making at the U.S. International Trade Commission", Journal of Law and Economics 36:915-35.

Anderson, Simon P., Schmitt, Nicolas, and Thisse, Jacques-Francois, 1995. "Who benefits from antidumping legislation?", Journal of International Economics, 38(3-4), 321-37.

Applebaum, Harvey M., and David R. Grace. "U.S. Antitrust Law and Antidumping Actions Under Title VII of the Trade Agreements Act of 1979." Antitrust Law Journal (1987): 497-518.

Bagwell, Kyle and Robert W. Staiger. (2016) "The Design of Trade Agreements," The Handbook of Commercial Policy, edited by Kyle Bagwell and Robert W. Staiger (Elsevier).

Baldwin, Robert E. (1985) The Political Economy of U.S. Import Policy. Cambridge, MA, MIT Press.

Baldwin, Robert E., and Jeffrey W. Steagall. (1994) "An Analysis of ITC Decisions in Antidumping, Countervailing Duty and Safeguard Cases", Weltwirtschaftliches Archiv/Review of World Economy 130(2):290-308.

Bao, Xiaohua, and Larry D. Qiu. (2011) “Is China's Antidumping More Retaliatory than that of the US?" Review of International Economics 19(2): 374-89.

Barceló, John J. (1991). A History of GATT Unfair Trade Remedy Law-Confusion of Purposes. The World Economy, 14(3), 311-333.

Baylis, Kathy, and Jeffrey M. Perloff. (2010) "Trade diversion from tomato suspension agreements", Canadian Journal of Economics, 43(1), 127-51.

Belderbos, Rene A. (1997) “Antidumping and Tariff Jumping: Japanese Firms' DFI in the European Union and the United States", Weltwirtschaftliches Archiv/Review of World Economy 133(3): 419-57. 
Belderbos, Rene, Hylke Vandenbussche, and Reinhilde Veugelers. (2004)

"Antidumping Duties, Undertakings, and Foreign Direct Investment in the EU", European Economic Review 48(2): 429-53.

Besedes, Tibor and Thomas J. Prusa. (2013) "Antidumping and the Death of Trade", NBER working paper 19555.

Blonigen , Bruce A. (2002) “Tariff-jumping Antidumping Duties”, Journal of International Economics 57(1): 31-49.

Blonigen, Bruce A. (2006a) "Working the System: Firm Learning and the Antidumping Process" European Journal of Political Economy 22(3): 715-31.

Blonigen, Bruce A. (2006b) "Evolving Discretionary Practices of U.S. Antidumping Activity." Canadian Journal of Economics 39(3): 874-900.

Blonigen, Bruce A. and Chad Bown. (2003) "Antidumping and Retaliation Threats", Journal of International Economics 60(2): 249-73.

Blonigen, Bruce A., and Stephen E. Haynes. (2002) "Antidumping Investigations and the Pass-Through of Exchange Rates and Antidumping Duties." American Economic Review 92(4): 1044-61.

Blonigen, Bruce A. and Jee-Hyeong Park. (2004) "Dynamic Pricing in the Presence of Antidumping Policy: Theory and Evidence", American Economic Review 94(1): 13454.

Blonigen, Bruce A., and Yuka Ohno. (1998) "Endogenous Protection, Foreign Direct Investment, and Protection-building Trade", Journal of International Economics 46(2): 205-27.

Blonigen, Bruce A. and Thomas J. Prusa, (2003) "Antidumping”, in E.Kwan Choi and James Harrigan (Eds.), Handbook of International Trade. Oxford, U.K. and Cambridge, MA: Blackwell Publishers, pp. 251-284.

Blonigen, Bruce A., KaSaundra Tomlin and Wesley W. Wilson (2004) "Tariff-jumping FDI and Domestic Firms' Profits", Canadian Journal of Economics 37(3): 656-77.

Blonigen, Bruce A., and Wesley W. Wilson. (2010)"Foreign subsidization and excess capacity." Journal of International Economics 80(2): 200-211.

Bown, Chad P. "Trade remedies and World Trade Organization dispute settlement: why are so few challenged?." The Journal of Legal Studies 34.2 (2005): 515-555.

Bown, Chad P. (2009) Self-Enforcing Trade: Developing Countries and WTO Dispute Settlement Washington, DC: Brookings Institution Press. 
Bown, Chad P. (2010) "Assessing the G20 Use of Antidumping, Safeguards, and Countervailing Duties During the 2008-2009 Crisis", in Simon J. Evenett (ed.), Unequal Compliance: The 6th GTA Report, London, UK: CEPR and VoxEU.org, 39-47 (chapter 3).

Bown, Chad P. (2011a) "Taking Stock of Antidumping, Safeguards and Countervailing Duties, 1990-2009”, The World Economy, 34(12),1955-98.

Bown, Chad P. (2011b) (ed.), The Great Recession and Import Protection: The Role of Temporary Trade Barriers. Washington, DC: The World Bank.

Bown, Chad P., (2013) "Emerging Economies and the Emergence of South-South Protectionism", Journal of World Trade, 47(1) 1-44.

Bown, Chad P. (2014a) "Global Antidumping Database", The World Bank, June, available at http://econ.worldbank.org/ttbd/gad/.

Bown, Chad P., (2014b) "Trade Policy Flexibilities and Turkey: Tariffs, Antidumping, Safeguards, and WTO Dispute Settlement", The World Economy 37(2): 193-218.

Bown, Chad P. and Alan O. Sykes, (2008) "The Zeroing Issue: A Critical Analysis of Softwood V", World Trade Review, 7(1), 121-142

Bown, Chad P. and Meredith A. Crowley. (2006) "Policy Externalities: How U.S. Antidumping Affects Japanese Exports to the E.U.", European Journal of Political Economy, 22(3), 696-714.

Bown, Chad P. and Meredith A. Crowley. (2007) "Trade Deflection and Trade Depression", Journal of International Economics, 72(1): 176-201.

Bown, Chad P. and Meredith A. Crowley. (2013) "Import Protection, Business Cycles, and Exchange Rates: Evidence from the Great Recession", Journal of International Economics, 90(1), 50-64.

Bown, Chad P. and Meredith A. Crowley. (2014) "Emerging Economies, Trade Policy, and Macroeconomic Shocks", Journal of Development Economies, 111, 261-73.

Bown, Chad P. and Meredith A. Crowley. (2016) "The Empirical Landscape of Trade Policy," The Handbook of Commercial Policy, edited by Kyle Bagwell and Robert W. Staiger (Elsevier).

Bown, Chad P, and Thomas J. Prusa. (2011) “U.S. Antidumping: Much Ado About Zeroing", in William J. Martin and Aaditya Mattoo (eds.), Unfinished Business? The WTO's Doha Agenda, London, UK: CEPR and World Bank 355-392. 
Bown, Chad P. and Patricia Tovar. (2011) "Trade Liberalization, Antidumping, and Safeguards: Evidence from India's Tariff Reform", Journal of Development Economics, 96(1): 115-25.

Brambilla, Irena, Guido Porto, and Alessandra Tarozzi. (2012) "Adjusting to Trade Policy: Evidence from U.S. Antidumping Duties on Vietnamese Catfish", Review of Economics and Statistics, Vol. 94(1): 304-19.

Brander, James, and Paul Krugman (1983) “A 'Reciprocal Dumping' Model of International Trade", Journal of International Economics 15(3-4): 313-21.

Brenton, Paul. (2001) "Anti-dumping Policies in the EU and Trade Diversion", European Journal of Political Economy 17(3): 593-607.

Carter, Colin A. and Gunning-Trant, Caroline, (2010), U.S. trade remedy law and agriculture: trade diversion and investigation effects. Canadian Journal of Economics, 43(1): 97-126.

Carter, Colin A. and Mohapatra, S., (2013), Inventories and antidumping: the case of orange juice trade, Empirical Economics, 45(1), 247-66.

Cassing, James and Ted To (2008) "Antidumping, signaling and cheap talk", Journal of International Economics, 75(2), 373-82.

Chandra, Piyush, and Cheryl Long. (2013) "Anti-Dumping Duties and its Impact on Exporters: Firm Level Evidence from China”, World Development, 51, 169-86.

Cheong, David (2007), "The Impact of EU Antidumping on Lower-income Countries", Johns Hopkins SAIS Working Paper.

Ciuriak, Dan. (2005). Anti-dumping at 100 Years and Counting: A Canadian Perspective. The World Economy, 28(5), 641-649.

Clarida, Richard. (1993) “Entry, Dumping, and Shakeout”, The American Economic Review, 83(1), 180-203.

Clarida, Richard. (1996) “Dumping: In Theory, In Policy, and in Practice”, in J. Bhagwati and R. Hudec, Eds., Fair Trade and Harmonization: Prerequisites for Free Trade?, Cambridge: MIT Press.

Cohen-Meidan, Maya, (2013), "The Heterogeneous Effects of Trade Protection: A Study of U.S. Antidumping Duties on Portland Cement", Review of Industrial Organization, 42(4), 369-94.

Cohen-Meidan, Maya, (2015), "Vertical Integration and Trade Protection: The Case of Antidumping Duties," Mimeo. 
Collie, David R. and Hylke Vandenbussche. (2006) "Tariffs and the Byrd Amendment", European Journal of Political Economy", 22(3): 750-8.

Davies, Ronald B., and Benjamin H. Liebman. (2006) "Self Protection? Antidumping Duties, Collusion, and FDI", Review of International Economics, 14(5): 741-57.

DeVault, James M. (1993) "Economics and the International Trade Commission", Southern Economic Journal 60(2): 463-478.

DeVault, James M. (1996a) "The Welfare Effects of U.S. Antidumping Duties", Open Economies Review 7(1): 19-33.

DeVault, James M. (1996b) “U.S. Antidumping Administrative Reviews”, International Trade Journal 10(2): 247-67.

Dixit, Avinash. (1988) "Anti-dumping and Countervailing Duties Under Oligopoly", European Economic Review 32(1): 55-68.

Durling, James P. and Thomas J. Prusa. (2006) "The Trade Effects Associated with an Antidumping Epidemic: The Hot-Rolled Steel Market, 1996-2001", European Journal of Political Economy 22(3), 675-95.

Egger, Peter, and Douglas Nelson. (2011). "How Bad is Antidumping? Evidence from Panel Data", Review of Economics and Statistics, 93(4): 1374-90.

Ethier, Wilfred J. (1982), “Dumping”, Journal of Political Economy, 90(3), 487-506.

Evenett, Simon J. (2006) "The Simple Analytics of U.S. Antidumping Orders: Bureaucratic Discretion, Anti-importer Bias, and the Byrd Amendment", European Journal of Political Economy", 22(3): 732-49.

Eymann, Angelika and Ludger Schuknecht. (1996) "Antidumping Policy in the European Community: Political Discretion or Technical Determination?" Economics and Politics 8(2): 111-31.

Feinberg, Robert M. (1989) "Exchange Rates and Unfair Trade”, Review of Economics and Statistics 71(4): 704-07.

Feinberg, Robert M. (2005) “U.S. Antidumping Enforcement and Macroeconomic Indicators Revisited: Do Petitioners Learn?" Weltwirtschaftliches Archiv/Review of World Economics, 141(4), 612-22.

Feinberg, Robert M., and Barry T. Hirsch. (1989) "Industry Rent Seeking and the Filing of 'Unfair Trade' Complaints", International Journal of Industrial Organization 7(3): 325-40.

Feinberg, Robert M., and Seth Kaplan. (1993) "Fishing Downstream: The Political Economy of Administered Protection", Canadian Journal of Economics 26(1): 150-58. 
Feinberg, Robert M., and Kara M. Reynolds (2006) "The Spread of Antidumping Regimes and the Role of Retaliation in Filing", Southern Economic Journal, 72(4): 877-90.

Feinberg, Robert M., and Kara M. Reynolds. (2007) “Tariff Liberalisation and Increased Administrative Protection: Is There a Quid Pro Quo?" World Economy 30(6): 948-61.

Feinberg, Robert M., and Kara M. Reynolds. (2008) "Friendly Fire? The Impact of U.S. Antidumping Enforcement on U.S. Exporters", Weltwirtschaftliches Archiv/Review of World Economy 144(2): 366-78.

Finger, J. Michael. (1993). Antidumping: How It Works and Who Gets Hurt, Ann Arbor, Michigan, U. of Michigan Press.

Finger, J. Michael, H. Keith Hall, and Douglas R. Nelson. (1982) “The Political Economy of Administered Protection", American Economic Review 72(3): 452-66.

Fischer, Ronald D. (1992) “Endogenous Probability of Protection and Firm Behavior", Journal of International Economics 32 (1-2): 149-63.

Gallaway, Michael P., Bruce A. Blonigen, and Joseph E. Flynn. (1999) "Welfare Costs of U.S. Antidumping and Countervailing Duty Laws", Journal of International Economics 49(2): 211-44.

Ganguli, Bodhisattva, (2008), "The Trade Effects of Indian Antidumping Actions", Review of International Economics, 16(5), 930-41.

Girma, Sourafel, David Greenaway, and Katherine Wakelin (2002) “Does Antidumping Stimulate FDI? Evidence from Japanese Firms in the UK", Weltwirtschaftliches Archiv/Review of World Economy 138(3): 414-36.

Gourlay, Sydney, and Kara M. Reynolds (2012), "Political Economy of Antidumping Reviews: The Impact of Discretion at the International Trade Administration", American University Department of Economics Working Paper.

Gruenspecht, Howard K. (1988), "Dumping and dynamic competition", Journal of International Economics, 25(3-4), 225-48.

Gupta, Poonam. (1999) “Why Do Firms Pay Antidumping Duty?" IMF Working Paper 99/166.

Gupta, Poonam and Panagariya, Arvind, (2001) "Injury Investigations in AntiDumping and the Super-Additivity Effect: A Theoretical Explanation", IMF Working Paper 01/110. 
Haaland, Jan I. and Ian Wooton. (1998) "Anti-dumping Jumping: Reciprocal Antidumping and Industrial Location", Weltwirtschaftliches Archiv/Review of World Economy 134(2): 340-62.

Hansen, Wendy L. (1990) "The International Trade Commission and the Politics of Protectionism", American Political Science Review 84(1): 21-46.

Hansen, Wendy L., and Thomas J. Prusa. (1996) “Cumulation and ITC Decision Making: The Sum of the Parts is Greater than the Whole", Economic Inquiry 34(4): 746-69.

Hansen, Wendy L., and Thomas J. Prusa. (1997) "The Economics and Politics of Trade Policy: An Empirical Analysis of ITC Decision Making", Review of International Economics 5(2): 230-45.

Hartigan, James C. (1994) "Dumping and Signaling”, Journal of Economic Behavior and Organization 23(1): 69-81.

Hartigan, James C. (1996) "Predatory Dumping”, Canadian Journal of Economics, 29(1): 228-39.

Hartigan, James C. (2000) "An Antidumping Law Can Be Procompetitive", Pacific Economic Review 5(1): 5-14.

Hartigan, James C., Sreenivas Kamma, and Philip R. Perry. (1989) “The Injury Determination Category and the Value of Relief from Dumping", Review of Economics and Statistics 71(1): 183-86.

Herander, Mark G. and J. Brad Schwartz. (1984) "An Empirical Test of the Impact of the Threat of U.S. Trade Policy: The Case of Antidumping Duties", Southern Economic Journal 51(1): 59-79.

Hillberry, Russell and Phillip McCalman. (2011) "What Triggers an Anti-Dumping Petition? Finding the Devil in the Detail", working paper.

Hoekman, Bernard M., and Michael P. Leidy. (1992) "Cascading Contingent Protection", European Economic Review 36(4): 883-92.

Hoekman, Bernard M., and Petros C. Mavroidis. "Competition, competition policy and the GATT." The World Economy 17.2 (1994): 121-150.

Howell, Thomas R., Noellert, William A., Krier, Jesse G., and Alan W. Wolf. (1988) Steel and the State: Government Intervention and Steel's Structural Crisis. Westview Press, London and Boulder, CO. 
Howse, Robert, and Robert W. Staiger. "United States-Anti-Dumping Act of 1916 (Original Complaint by the European Communities)-Recourse to arbitration by the United States under 22.6 of the DSU, WT/DS136/ARB, 24 February 2004." World Trade Review 4.02 (2005): 295-316.

Hughes, John S., Stefanie Lenway and Judy Rayburn, (1997), "Stock Price Effects of U.S. Trade Policy Responses to Japanese Trading Practices in Semi-Conductors", The Canadian Journal of Economics, 30(4), 922-42.

Irwin, Douglas A. (1998), "The semiconductor industry", in Robert Z. Lawrence (ed.), Brookings Trade Forum 1998, Washington, DC: Brookings Institution Press.

Irwin, Douglas A. (2005) “The Rise of U.S. Anti-dumping Activity in Historical Perspective", World Economy 28(5): 651-68.

Janow, Merit E. and Robert W. Staiger (2003) "European Communities - AntiDumping Duties on Imports of Cotton-Type Bed Linen from India", in Petros Mavroidis and Henrik Horn (eds.) The WTO Case Law of 2001. Cambridge University Press: Cambridge, UK.

Knetter, Michael M. and Thomas J. Prusa. (2002) "Macroeconomic Factors and Antidumping Filings: Evidence from Four Countries", Journal of International Economics, 61(1): 1-18.

Kobayashi, Bruce H. (2010) "The Law and Economics of Predatory Pricing" in Hylton, Keith N. (ed.) Antitrust Law and Economics. Edward Elgar, 116-156.

Kohler, Philippe and Michael O. Moore. (2001) "Injury-based Protection with Auditing under Imperfect Information", Southern Economic Journal 68(1): 42-59.

Kolev, Dobrin R., and Thomas J. Prusa. (2002) "Dumping and Double Crossing: The (In)Effectiveness of Cost-Based Trade Policy Under Incomplete Information", International Economic Review 43(3): 895-918.

Konings, Jozef, and Hylke Vandenbussche. (2005) "Antidumping Protection and Markups of Domestic Firms: Evidence from Firm Level Data", Journal of International Economics 65(1): 151-65.

Konings, Jozef, and Hylke Vandenbussche. (2008) "Heterogeneous Responses of Firms to Trade Protection", Journal of International Economics 76(2): 371-83.

Konings, Jozef, Hylke Vandenbussche, and Linda Springael. (2001) "Import Diversion under European Antidumping Policy", Journal of Industry, Competition and Trade 1(3): 283-99.

Krupp, Corinne. (1994) "Antidumping Cases in the U.S. Chemical Industry: A Panel Data Approach", Journal of Industrial Economics 42(3): 299-311. 
Krupp, Corinne M., and Patricia S. Pollard. (1996) "Market Responses to Antidumping Laws: Some Evidence from the U.S. Chemical Industry", Canadian Journal of Economics 29(1): 199-227.

Lasagni, Andrea, (2000), "Does Country-targeted Anti-dumping Policy by the EU Create Trade Diversion?", Journal of World Trade, 34(4), 137-60.

Leidy, Michael P. (1997) "Macroeconomic Conditions and Pressures for Protection Under Antidumping and Countervailing Duty Laws: Empirical Evidence from the United States", International Monetary Fund Staff Papers 44, 132-44

Lichtenberg, Frank and Hong Tan. (1994) “An Industry-Level Analysis of Import Relief Petitions Filed by U.S. Manufacturers, 1958-1985", in Hong Tan and Haruo Shimada (eds.), Troubled Industries in the United States and Japan, New York: St. Martin's Press, 161-88.

Liebman, Benjamin H. (2004) "ITC Voting Behavior on Sunset Reviews", Weltwirtschaftliches Archiv/Review of World Economics 140(3): 446-75.

Liebman, Benjamin H., and Kara M. Reynolds. (2006) "The Returns from Rentseeking: Campaign Contributions, Firm Subsidies, and the Byrd Amendment", Canadian Journal of Economics 39(4): 1345-69.

Lindsey, Brink (2000) "The U.S. Antidumping Law: Rhetoric versus Reality", Journal of World Trade 34(1): 1-38.

Lindsey, Brink and Daniel J. Ikenson (2002) "Antidumping 101: The Devilish Details of 'Unfair Trade' Law”, Cato Institute Trade Policy Analysis No. 20.

Lindsey, Brink and Daniel J. Ikenson (2003) Antidumping Exposed: The Devilish Details of Unfair Trade Law, Cato Institute: Washington, DC.

Lu, Yi, Zhigang Tao, and Yan Zhang. (2013) "How Exporters Respond to Antidumping Investigations?", Journal of International Economics, 91(2), 290-300.

Ludema, Rodney D. and Anna Maria Mayda (2011) "Canada: No Place Like Home for Antidumping", in Chad P. Bown (ed.), The Great Recession and Import Protection: The Role of Temporary Trade Barriers. Washington, DC: The World Bank: 131-61.

Martin, Alberto, and Wouter Vergote, (2008) "On the Role of Retaliation in Trade Agreements", Journal of International Economics, 76(1), 61-77.

Mastel, Greg. (1998). Antidumping Laws and the U.S. Economy. Armonk, NY: ME Sharpe.

Maur, Jean-Christophe, (1998) “Echoing Antidumping Cases: Regulatory Competitors, Imitation and Cascading Protection", World Competition, 21(6). 51-84. 
Messerlin, Patrick. 2001. Measuring the costs of protection in Europe: European commercial policy in the 2000s. Washington, DC: Institute for International Economics.

Miranda, Jorge, Raul. A. Torres, and Mario Ruiz. (1998) “The International Use of Antidumping: 1987-1997", Journal of World Trade, 32(1): 5-71

Miyagiwa Kaz, and Yuka Ohno. (1995) “Closing the Gap Under Protection”, American Economic Review, 85(14): 755-70.

Miyagiwa Kaz, and Yuka Ohno. (2007) “Dumping as a Signal of Innovation”, Journal of International Economics, 71(1): 221-40.

Miyagiwa, Kaz, Huasheng Song, and Hylke Vandenbussche. (2010) "Innovation, Antidumping, and Retaliation", CORE Discussion Paper 2010/64.

Moore, Michael O. (1992) "Rules or Politics? An Empirical Analysis of ITC Antidumping Decisions”, Economic Inquiry 30(3): 449-66.

Moore, Michael O. (1999) “Antidumping Reform in the US: A Faded Sunset” Journal of World Trade, 33(4): 1-28.

Moore, Michael O. (2006a) "An Econometric Analysis of U.S. Antidumping Sunset Review Decisions", Weltwirtschaftliches Archiv/Review of World Economics 142(1): 122-50.

Moore, Michael O. (2006b) “U.S. 'Facts Available’ Antidumping Decisions: An Empirical Analysis", European Journal of Political Economy, 22(3): 639-52.

Moore, Michael 0. and Maurizio Zanardi. (2009) "Does Antidumping Use Contribute to Trade Liberalization in Developing Countries?" Canadian Journal of Economics 42(2): 469-95.

Moore, Michael 0. and Maurizio Zanardi. (2011) "Trade Liberalization and Antidumping: Is There a Substitution Effect?" Review of Development Economics 15(4): 601-19.

Morck, Randall, Jungsywan Sepanski, and Bernard Yeung. (2001) "Habitual and Occasional Lobbyers in the U.S. Steel Industry: An EM Algorithm Pooling Approach", Economic Inquiry 39(3): 365-78.

Morkre, Morris E. and Kenneth H. Kelly. (1998) "Effects of Unfair Imports on Domestic Industries: U.S. Antidumping and Countervailing Duty Cases, 1980-1988", Federal Trade Commission Bureau of Economics Staff Report. 
Murray, Tracy, and Donald J. Rousslang. (1989) "A Method for Estimating Injury Caused by Unfair Trade Practices", International Review of Law and Economics 9(2): 149-64.

Nelson, Douglas. (2006) "The Political Economy of Antidumping: A Survey", European Journal of Political Economy 22(3): 554-90.

Niels, Gunnar, and Joseph Francois. (2006) "Business Cycles, the Exchange Rate, and Demand for Antidumping Protection in Mexico", Review of Development Economics 10(3): 388-99.

Niels, Gunnar. (2003) Trade Diversion and Destruction Effects of Antidumping Policy: Empirical Evidence from Mexico", Mimeo.

Panagariya, Arvind and Poonam Gupta. (1998) "Anti-dumping Duty versus Price Competition", World Economy 21(8): 1003-19.

Park Soonchan. (2009) "The Trade Depressing and Trade Diversion Effects of Antidumping Actions: The Case of China", China Economic Review 20(3): 542-48.

Pierce, Justin R. (2011) "Plant-level Responses to Antidumping Duties: Evidence from U.S. Manufacturers" Journal of International Economics 85(2): 222-33.

Prusa Thomas J. (1992) “Why Are So Many Antidumping Petitions Withdrawn?" Journal of International Economics, 33(1-2):1-20.

Prusa Thomas J. (1994) "Pricing Behavior in the Presence of Antidumping Law", Journal of Economic Integration 9(2): 260-89.

Prusa Thomas J. (1997) “The Trade Effects of U.S. Antidumping Actions”, in Robert C. Feenstra (ed.), The Effects of U.S. Trade Protection and Promotion Policies. Chicago, IL: University of Chicago Press, 191-213. 20.

Prusa, Thomas J., (1998) "Cumulation and antidumping: A challenge to competition." The World Economy 21(8), 1021-1033.

Prusa Thomas J. (2001), "On the Spread and Impact of Antidumping”, Canadian Journal of Economics 34(3): 591-611.

Prusa, Thomas J. (2005) "Anti-dumping: A Growing Problem in International Trade", World Economy 28(5): 683-700.

Prusa, Thomas J. and Robert Teh, (2010) "Protection Reduction and Diversion: PTAs and the Incidence of Antidumping Disputes." NBER working paper 1627.

Prusa, Thomas J. and Susan Skeath (2002) "The Economic and Strategic Motives for Antidumping Filings", Weltwirtschaftliches Archiv/Review of World Economics 138(3): 389-413. 
Prusa, Thomas J., (2011) “United States: Evolving Trends in Temporary Trade Barriers." in Chad P. Bown (ed.), The Great Recession and Import Protection: The Role of Temporary Trade Barriers. Washington, DC: The World Bank: 53-83.

Prusa, Thomas J., and Susan Skeath. (2005) "Modern Commercial Policy: Managed Trade or Retaliation", in E. Kwan Choi and James Hartigan (Eds.), Handbook of International Trade: Economic and Legal Analyses of Trade Policy and Institutions, Volume II. Oxford, U.K. and Cambridge, MA: Blackwell Publishers.

Prusa, Thomas J. and Edwin Vermulst, (2009) "A One-Two Punch on Zeroing: U.S. Zeroing (EC) and U.S. - Zeroing (Japan).”World Trade Review 8(1) 187-241.

Prusa, Thomas J. and Edwin Vermulst, (2011) “United States - Continued existence and application of zeroing methodology: The end of zeroing?" World Trade Review 10(1) 45-61.

Reitzes, James D. (1993) “Antidumping Policy”, International Economic Review 34(4): 745-63.

Reynolds, Kara. (2006) "Subsidizing Rent-Seeking: Antidumping Protection and the Byrd Amendment", Journal of International Economics 70(2): 490-502.

Rosendorff, B. Peter. (1996) "Voluntary Export Restraints, Antidumping Procedure, and Domestic Politics", American Economic Review 86(3): 544-61.

Rosendorff, B. Peter and Milner, Helen. (2001) "The Optimal Design of International Trade Institutions: Uncertainty and Escape”, International Organization 55 (4), 829857.

Rutkowski, A. (2007) "Withdrawals of Anti-dumping Complaints in the EU: A Sign of Collusion", World Economy 30(3): 470-503.

Sabry, Faten. (2000) "An Analysis of the Decision to File, the Dumping Estimates, and the Outcome of Antidumping Petitions", International Trade Journal 14(2): 10945.

Shin, Hyun Ja. (1998) Possible Instances of Predatory Pricing in Recent U.S. Antidumping Cases, in Brookings Trade Forum. Washington, DC: The Brookings Institution, pp. 81-97

Staiger, Robert W. and Frank A. Wolak. (1989) "Strategic Use of Antidumping Law to Enforce Tacit International Collusion", NBER Working Paper, No. 3016.

Staiger, Robert W., and Frank A. Wolak. (1992) "The Effect of Domestic Antidumping Law in the Presence of Foreign Monopoly", Journal of International Economics 32(34): 265-87. 
Staiger, Robert W., and Frank A. Wolak. (1994) “Measuring Industry Specific Protection: Antidumping in the United States", Brookings Papers on Economic Activity: Microeconomics: 51-118.

Sykes, Alan 0., and Richard N. Cooper. "Antidumping and Antitrust: What Problems Does Each Address? [with Comments and Discussion]." Brookings Trade Forum. Brookings Institution Press, 1998.

Tarullo, Daniel K. "Hidden Costs of International Dispute Settlement: WTO Review of Domestic Anti-Dumping Decisions, The." Law \& Pol'y Int'l Bus. 34 (2002): 109.

Taylor, Christopher T. (2004) "The Economic Effects of Withdrawn Antidumping Investigations: Is there Evidence of Collusive Settlements", Journal of International Economics 62(2): 295-312.

Tharakan, P.K.M. (1991) "The Political Economy of Anti-dumping Undertakings in the European Communities", European Economic Review 35(6): 1341-59.

Tharakan, P.K.M. (1999) "Predatory Pricing and Anti-dumping", in G. Norman and J.F. Thisse (eds.), Market Structure and Competition Policy. Cambridge, UK: Cambridge University Press.

Tharakan P.K.M., David Greenaway, Joe Tharakan. (1998) "Interface Between Antidumping Policy and Competition Policy: A Case Study", World Economy 21(8): 103560 .

Tharakan, P.K.M., and J. Waelbroeck. (1994a) “Determinants of Anti-dumping and Countervailing Duty Decisions in the European Communities", in Mathias Dewatripont and Victor Ginsburgh (eds.), European Economic Integration: A Challenge in a Changing World. Amsterdam, London, and Tokyo: North Holland, 18199.

Tharakan, P.K.M., and J. Waelbroeck. (1994b) “Antidumping and Countervailing Duty Decisions in the E.C. and in the US: An Experiment in Comparative Political Economy", European Economic Review 38(1): 171-93.

Vandenbussche, Hylke and Christian Viegelahn (2011), "European Union: No Protectionist Surprises" (Chapter 3), in in Chad P. Bown (ed.), The Great Recession and Import Protection: The Role of Temporary Trade Barriers. Washington, DC: The World Bank: 85-129.

Vandenbussche, Hylke and Maurizio Zanardi. (2008). "What Explains the Proliferation of Antidumping Laws?" Economic Policy, 23(53): 94-138.

Vandenbussche, Hylke and Maurizio Zanardi. (2010) "The Chilling Trade Effects of Antidumping Proliferation", European Economic Review 54(6): 760-77. 
Veugelers, Reinhilde, and Hylke Vandenbussche. (1999) "European Anti-Dumping Policy and the Profitability of National and International Collusion", European Economic Review 43(1): 1-28.

Victor, A. Paul. "Antidumping and Antitrust: Can the Inconsistencies be Resolved." NYUJ Int'l L. \& Pol. 15 (1982): 339.

World Trade Organization (WT0) (2009) World Trade Report 2009, Geneva: World Trade Organization.

Yoshitomo, Ogawa, and Yoshiyasu Ono. (2011) "The Byrd Amendment as Facilitating a Tacit International Business Collusion", Review of International Economics 19(5): 877-93.

Zanardi, Maurizio. (2004a) "Antidumping: What are the Numbers to Discuss at Doha?", The World Economy 27(3), 403-33.

Zanardi, Maurizio. (2004b) "Antidumping Law as a Collusive Device", Canadian Journal of Economics 37(1): 95-122. 
Figure 1: Countries with AD Laws, 1900-2014

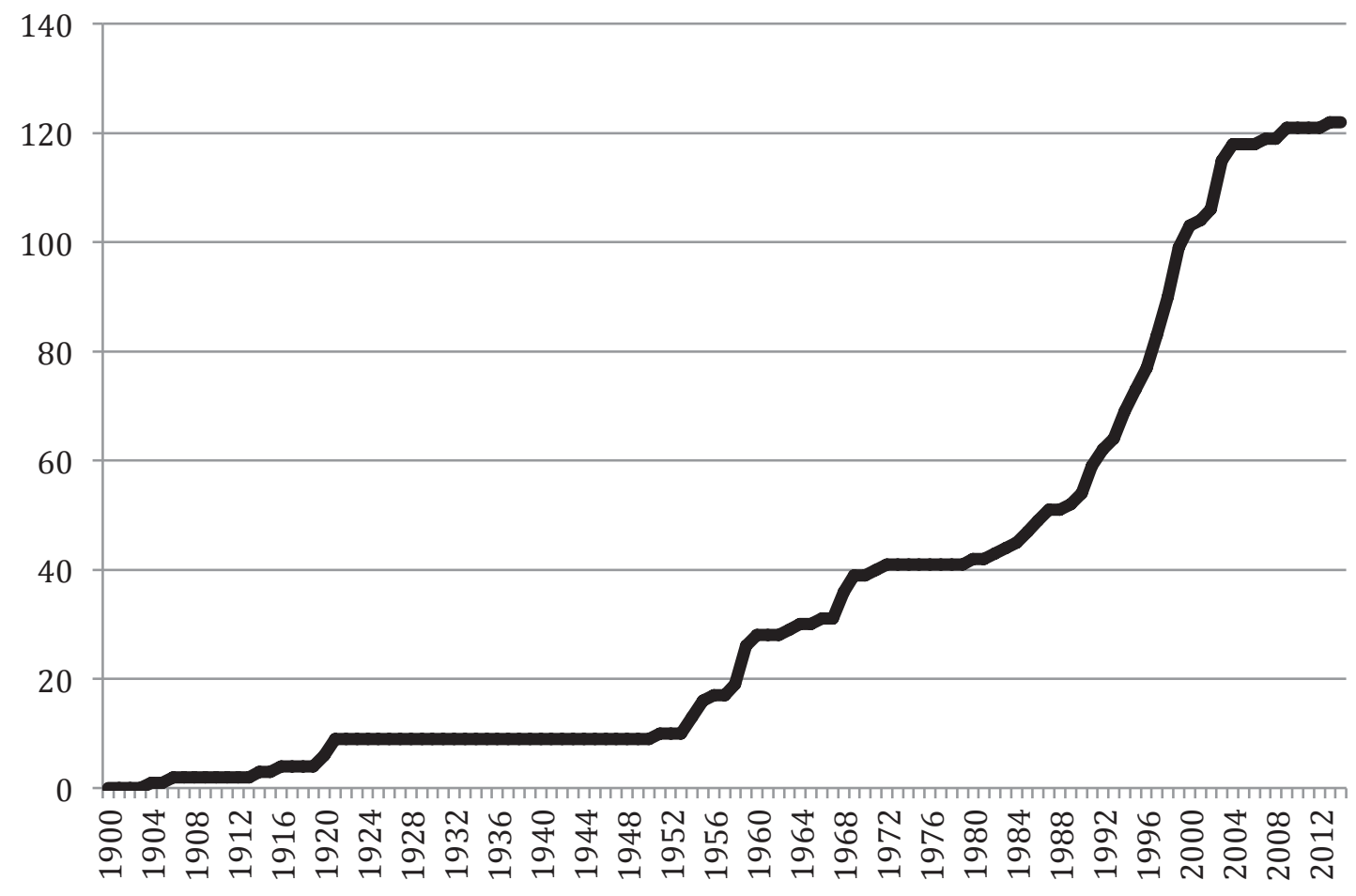

Source: Vandenbussche and Zanardi (2008). Updated by the authors to include most recent years using online WTO resources and changes in membership of customs and monetary unions with existing AD laws. Detailed country list available upon request. 
Figure 2: Annual AD Initiations and Measures by WTO Members, 1995 - 2013

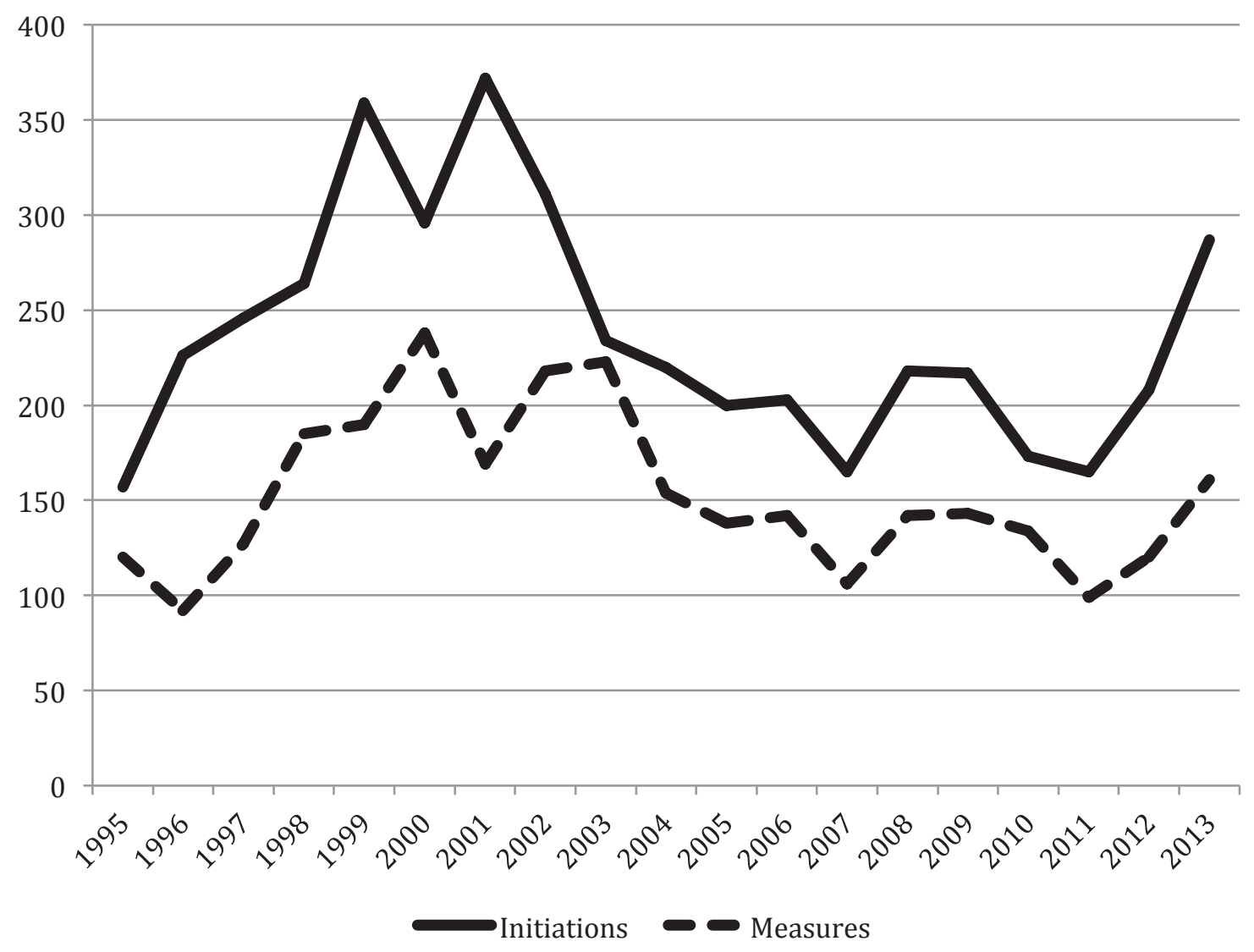

Source: Official WTO statistics available online at https://www.wto.org/english/tratop_e/adp_e/adp_e.htm. 
$\stackrel{\infty}{\wedge}$

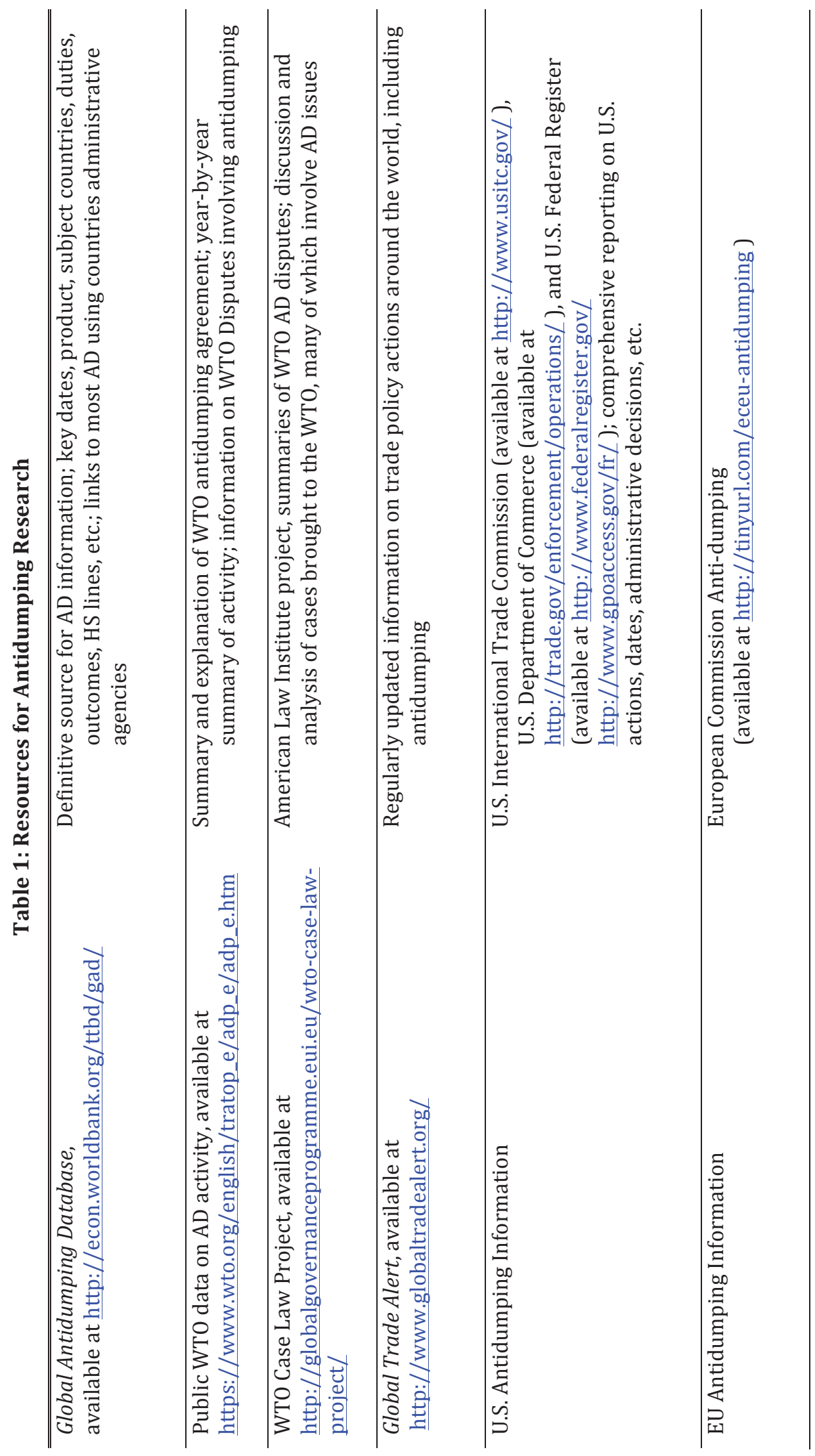


Table 2: Countries That Apply and That Are Targeted by AD Measures

\begin{tabular}{|c|c|c|c|c|c|}
\hline \multicolumn{4}{|c|}{ Top Users } & \multicolumn{2}{|c|}{ Top Targets } \\
\hline & \multirow{2}{*}{$\begin{array}{c}\text { Case } \\
\text { Count* }\end{array}$} & \multicolumn{2}{|c|}{$\begin{array}{c}\text { HS Tariff Line } \\
(\% \text { covered })\end{array}$} & & \multirow{2}{*}{$\begin{array}{l}\text { Case } \\
\text { Count* }\end{array}$} \\
\hline & & Count** & Trade $\mathrm{Wtd}^{* * *}$ & & \\
\hline India & 519 & 6.9 & 5.8 & China & 719 \\
\hline U.S.A & 323 & 5.8 & 3.9 & South Korea & 201 \\
\hline E.U. & 297 & 3.1 & 1.7 & Taiwan & 162 \\
\hline Argentina & 219 & 3.3 & 2.5 & U.S. & 150 \\
\hline Brazil & 165 & 1.9 & 1.7 & Japan & 126 \\
\hline China & 164 & 1.4 & 3.2 & Thailand & 121 \\
\hline Turkey & 154 & 6.9 & 2.6 & Indonesia & 110 \\
\hline South Africa & 131 & 0.6 & 0.3 & Russia & 105 \\
\hline Canada & 113 & 1.1 & 0.7 & India & 103 \\
\hline Australia & 108 & 0.7 & 0.4 & Brazil & 86 \\
\hline
\end{tabular}

* $1995-2013$

** TTB coverage (2011)

*** AD coverage (2011)

Source: Case Count from official WTO statistics available online at www.wto.org/english/tratop_e/adp_e/adp_e.htm; AD and TTB coverage at tariff line level from Bown (2013) 
Table 3: Bilateral AD Use

\begin{tabular}{|c|c|c|c|}
\hline Importer & Exporter & No. of AD Cases* & $\begin{array}{c}\text { Share of Target's } \\
\text { Bilateral Exports } \\
\text { Subject to TTB (\%)** }\end{array}$ \\
\hline India & China & 132 & 23.2 \\
\hline U.S. & China & 97 & 9.1 \\
\hline E.U. & China & 85 & 7.3 \\
\hline Argentina & China & 68 & 10.9 \\
\hline Turkey & China & 60 & 15.7 \\
\hline Brazil & China & 50 & 18.8 \\
\hline India & E.U. & 41 & -- \\
\hline India & Taiwan & 41 & -- \\
\hline India & Korea & 39 & 7.2 \\
\hline Argentina & Brazil & 37 & -- \\
\hline China & U.S. & 33 & 6.7 \\
\hline China & Japan & 29 & -- \\
\hline India & Thailand & 28 & 7.7 \\
\hline China & Korea & 27 & 4.3 \\
\hline India & U.S. & 26 & -- \\
\hline Canada & China & 25 & 3.6 \\
\hline India & Japan & 25 & -- \\
\hline U.S. & Japan & 22 & -- \\
\hline India & Indonesia & 22 & -- \\
\hline Mexico & U.S. & 21 & 0.9 \\
\hline Colombia & China & 21 & 3 \\
\hline China & E.U. & 20 & -- \\
\hline E.U. & India & 20 & 1.3 \\
\hline South Africa & China & 20 & 1.4 \\
\hline
\end{tabular}

* $1995-2013$

** 2013

Source: Case Count from official WTO statistics available online at

www.wto.org/english/tratop_e/adp_e/adp_e.htm.; 2013 TTB coverage at tariff line level from Bown (2014a) 
Table 4: Bilateral TTB Coverage (2013)

\begin{tabular}{|c|c|c|}
\hline Importer & Exporter & $\begin{array}{c}\text { Share of Target's Bilateral Exports } \\
\text { Subject to TTB (\%) }\end{array}$ \\
\hline Jordan & Belarus & 100.0 \\
\hline Jordan & Libya & 95.5 \\
\hline Turkey & Kuwait & 65.6 \\
\hline Chile & Paraguay & 54.5 \\
\hline U.S.A. & Ukraine & 53.6 \\
\hline Argentina & Kazakhstan & 47.9 \\
\hline U.S.A. & Latvia & 40.7 \\
\hline Turkey & Oman & 37.2 \\
\hline Peru & Pakistan & 35.6 \\
\hline Thailand & Kazakhstan & 34.3 \\
\hline India & Slovenia & 33.7 \\
\hline Mexico & Ukraine & 31.3 \\
\hline Colombia & Trinidad and Tobago & 31.0 \\
\hline U.S.A. & Moldova & 31.0 \\
\hline India & Kenya & 30.7 \\
\hline Indonesia & Macao & 30.2 \\
\hline Ukraine & Japan & 29.1 \\
\hline Ukraine & Kuwait & 28.1 \\
\hline Brazil & New Zealand & 27.0 \\
\hline India & Belarus & 26.1 \\
\hline Colombia & Turkey & 25.9 \\
\hline Brazil & Bangladesh & 23.3 \\
\hline India & China & 23.2 \\
\hline Brazil & China & 18.8 \\
\hline U.S.A. & Russia & 18.6 \\
\hline Ukraine & Mexico & 18.1 \\
\hline Canada & Bulgaria & 17.0 \\
\hline Turkey & China & 15.7 \\
\hline Chile & Czech Republic & 15.5 \\
\hline Ukraine & South Korea & 15.4 \\
\hline Ukraine & Uzbekistan & 15.4 \\
\hline Turkey & India & 15.3 \\
\hline Morocco & Portugal & 15.1 \\
\hline
\end{tabular}

Source: Bown (2014a). 
Table 5: Average AD Duties for Selected Users (percent)

\begin{tabular}{ccc}
\hline Users & $\begin{array}{c}\text { Average Applied MFN } \\
\text { Tariff Rates } \\
\text { Average AD duties } \\
\text { (1980-2005) }\end{array}$ & $\begin{array}{c}\text { 2007) } \\
\text { (1996- }\end{array}$ \\
\hline \hline Developed & 12.1 & 4.2 \\
Canada & 17.6 & 6.4 \\
EC & 41.4 & 5.2 \\
U.S. & & \\
Developing & 21.4 & 13.8 \\
China & 89.5 & 15.8 \\
Mexico & 21.5 & 8.5 \\
Indonesia & 27.4 & 12.6 \\
South Korea & 30.9 & 10.9 \\
Peru & 29.1 & 7.0 \\
South Africa & 29.1 & 12.9 \\
Turkey &
\end{tabular}

Source: WTO (2009), p 130. 


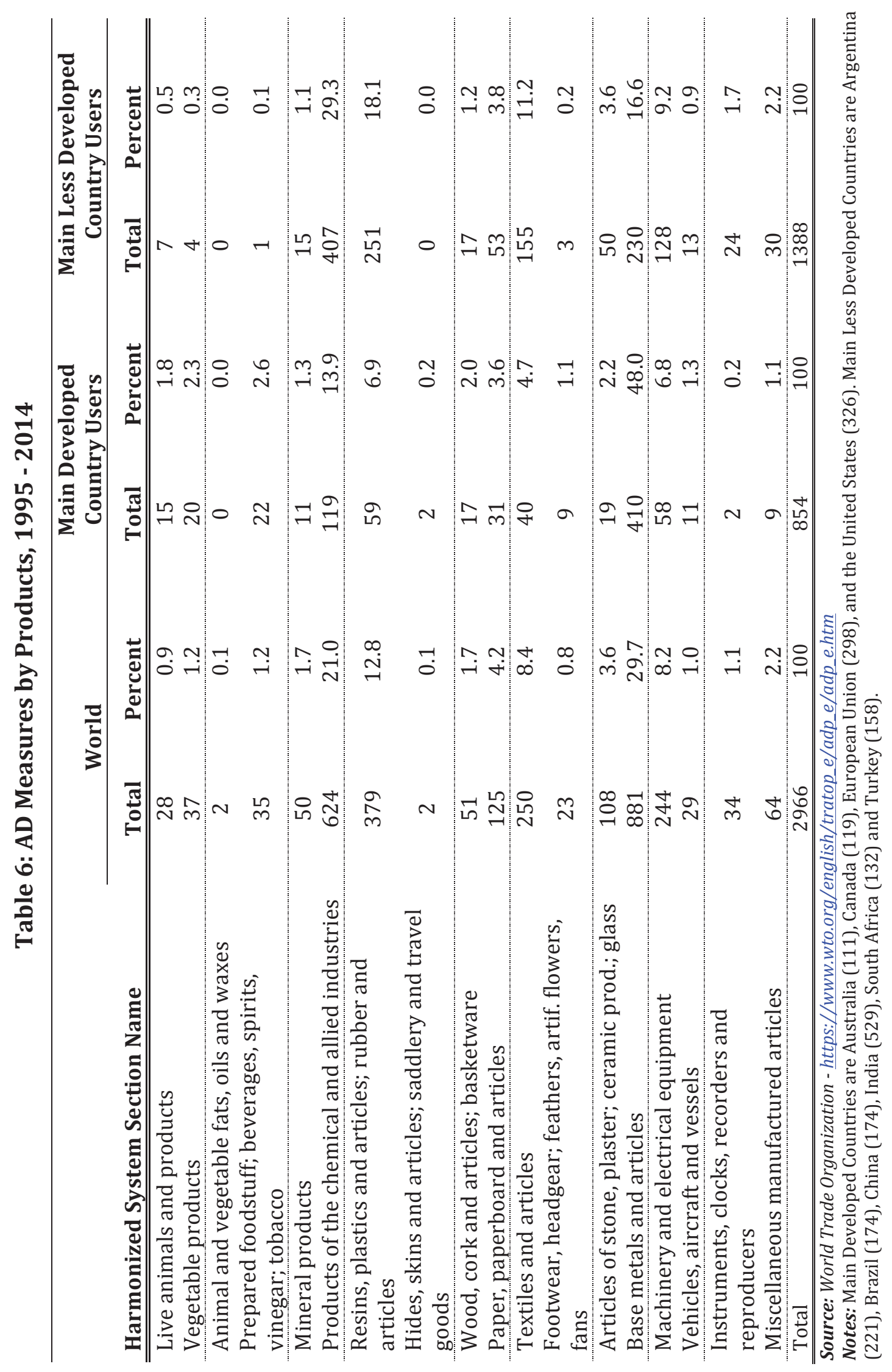

$\infty$ 


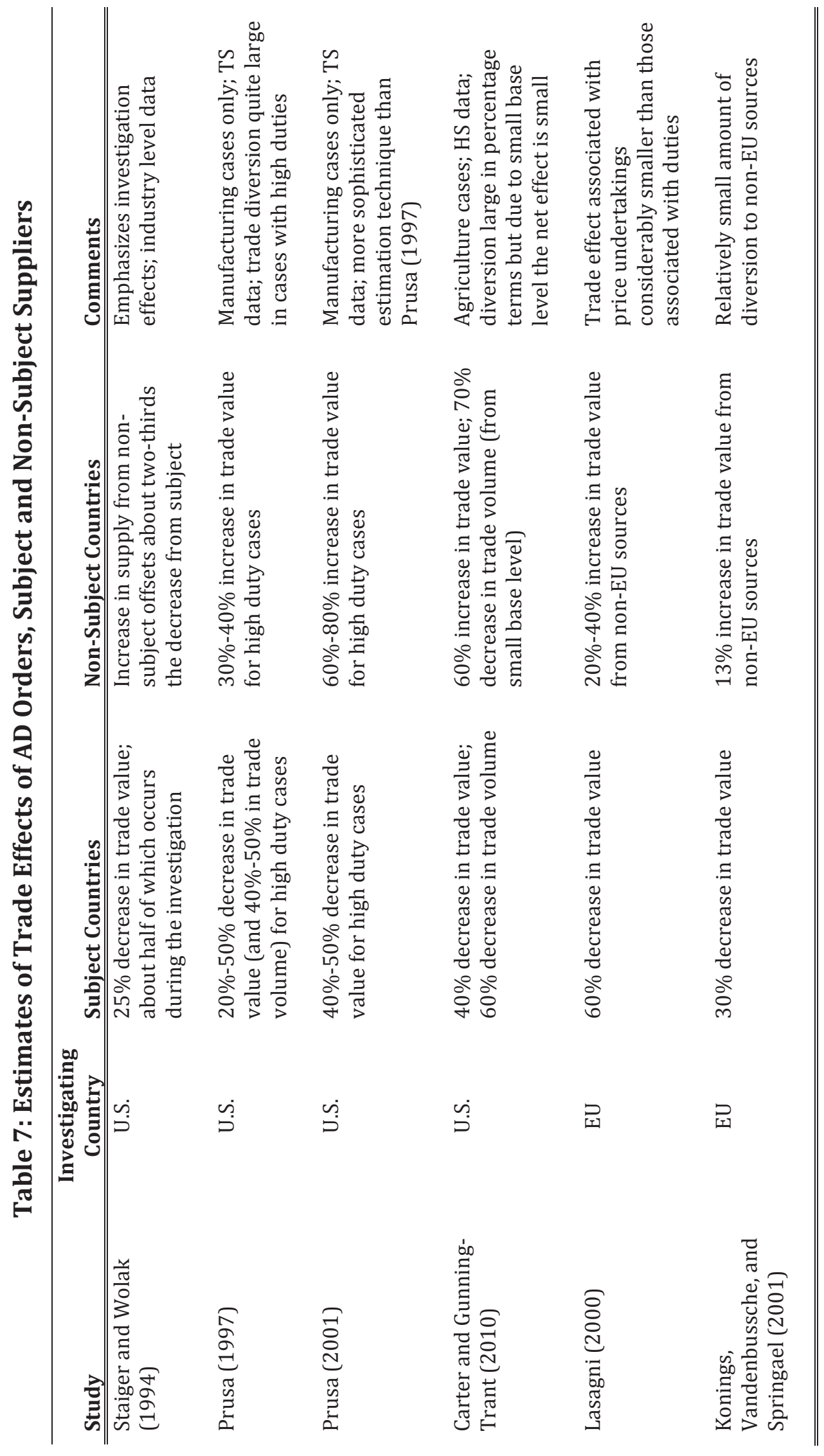

‡ 